$1-1-1939$

\title{
Certain economic aspects of agriculture in the Jackson County Soil-conservation Area
}

\author{
E. C. Weitzell
}

Follow this and additional works at: https://researchrepository.wvu.edu/ wv_agricultural_and_forestry_experiment_station_bulletins

\section{Digital Commons Citation}

Weitzell, E. C., "Certain economic aspects of agriculture in the Jackson County Soil-conservation Area" (1939). West Virginia Agricultural and Forestry Experiment Station Bulletins. 291.

https://researchrepository.wvu.edu/wv_agricultural_and_forestry_experiment_station_bulletins/292 


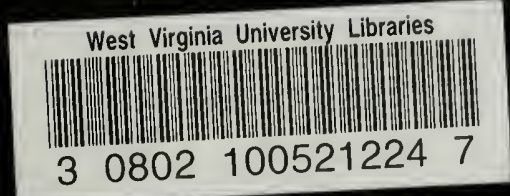



Certain Economic Aspects of Agriculture in the

\section{Jackson County Soil-Conservation Area}

by E. C. WEITZELL

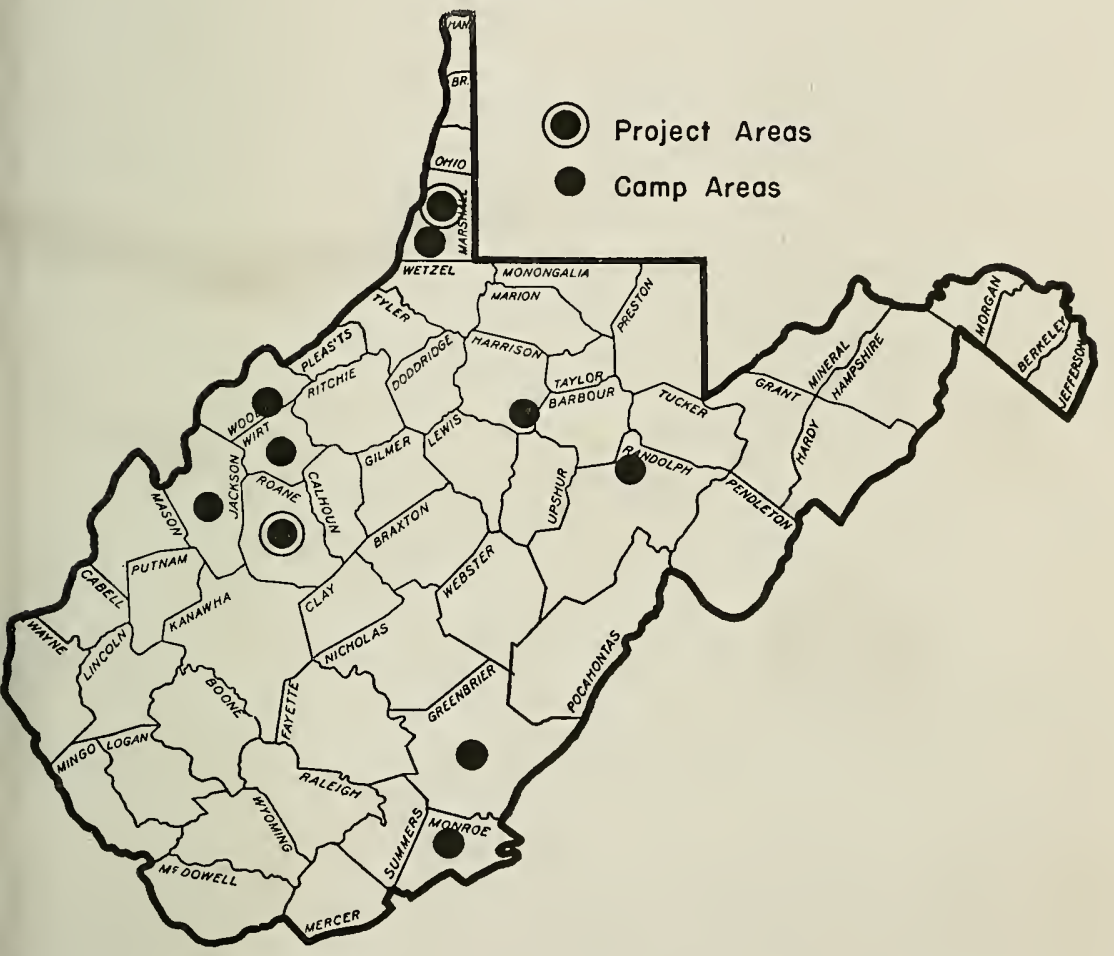

Location of Lemonstration Projects of Soil Conservation in West Virginia

AGRICULTURAL EXPERIMENT STATION COLLEGE OF AGRICULTURE, FORESTRY, AND HOME ECONOMICS WEST VIRGINIA UNIVERSITY

C. R. ORTON, Director MORGANTOWN 
Objectives of Study

Description of the Jackson Demonstration Area

\section{Location}

Topography

Soils

Climate

Land Classification

Social Aspects of Farm Families -

Áge of Farmer's _......

Background of Farmers _...

Farm Families

Conditions Affecting Social and Economic Planning _......... 9

Agricultural Production _._. 10

Size of Farms 10

Investment

The Character of Farming

Land Use _.

Farm Practices _._.

Crops - Pron 14

Erosion Resistance of Crops

Crop Yields

Pasture Capacities

Crop Sales

Livestock 19

Animal Units

Livestock Inventory

Livestock Purchases and Sales _._._._._._._. 20

Livestock Products

Miscellaneous Farm Income

Non-Agricultural Income _..._._.

Total Farm Receipts _._.

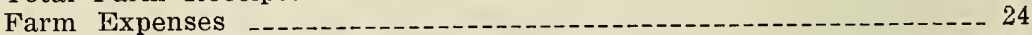

Farm Business Summary _._.

Types of Farming

General Farms _. 29

Size of Business

Efficiency of Operation

Organization and Combination of Enterprises _..... 33

Specialized Beef-Cattle Farms _._._.

Size of Business

Efficiency of Operation

Organization and Combination of Enterprises _............ 37

Conclusion for Beef-Cattle Farms _........... 38

Self-Sufficing Farms

Size of Business

Organization of Farms _.......... 40

Yields and Production

Expenses and Income

Poultry Farms _... 43

Part-Time Farms _._- 44

Dairy Farms

The Program of Soil Conservation in the Jackson Area

(1) Pasture Improvement _.

(2) Yield Improvement _............ 48

(3) Improvement and Conservation of Soil Fertility

(4) Lime and Fertilizer -

(5) Farm Organization and Management _.................. 49

(6) Vegetation and Cover

(7) Engineering -.... 49

(8) Forest Plantings

Farm Planning _. 50

Summary -

Appendix _- 53 


\section{Certain Economic Aspects of Agriculture in the}

\section{Jackson County Soil-Conservation Area}

\section{by E. C. WEITZELL1}

\section{$\mathrm{T}$}

HE USE OF LAND in West Virginia presents many problems. Practically one-fourth of the population depends directly on agriculture for a livelihood, while the remaining three-fourths must receive its food supply from this or other states. Mining, lumbering, and industry in the past have contributed the major proportion of the income. As these resources were depleted, an increasing proportion of the population has turned to the soil for a larger amount of its livelihood.

Land suitable for the most efficient crop production is limited to small areas of limestone, sedimentary, and residual soils of lesser slopes. Hence more food is necessary to support the population than can be produced on these limited areas. As a result, crops are being grown on steeply-sloping land that erodes rapidly under comparatively intensive cultivation. Soil depletion and low crop yiclds follow.

In general, farmers have been very slow to solve the problems of soil managenent that accompany hill farming. There has been practically no attempt to effect management practices that would conserve and prolong a large part of the original productive capacity of the hillside soils. Consequently, erosion and depletion of essential production elements have been responsible for the abandonment of much originally good hillside land. One generation has heen known to clear the land of forest, "wear out," and abandon two or more farms. Depleted crop land often has been diverted to low quality pasture or it has been abandoned to brish and second-growth timber.

Such exploitative procedure was possible in the past. New land for farming is now scarce. Attention must be given to conserving and maintaining land already cleared. Many social and econonic considerations are basic to the correct planning of a long-time program of land conservation.

1Assistant Agricultural Economist, Department of Agricultural Economics, West Virginia University; The Research Division. Soil Conservation Service: and the Bureau of Agricultural Economics, Inited States Department of Agriculture, cooperating.

ACKNOWLEDGMENT: The author wishes to acknowledge the diligent clerisal assistance rendered by Gertrune A. Lucas and I. B. Darrah. The conperation of the farmers of Jackson County and of the members of the operations staff of the Soil Conservation Service is appreciated. 


\section{Objectives of Study}

In connection with the operations of the Soil Conservation Service, the research division was established to obtain facts and to develop relationships in the field of soil and water conservation. In this work the West Virginia Agricultural Experiment Station is cooperating with the Bureau of Agricultural Economics and the Soil Conservation Service; United States Department of Agriculture.

The present project was established in 1936 to study the effects of the program of soil conservation on farms in the demonstration areas. The project was designed to obtain labor income and farm practice records on the farms in each successive year for a five-ycar period. so that the progress and benefits of the program could be measured.

This refort is intended to portray basic agricultural conditions prior to the introduction of the conservation program and through the first year of its operation. The data included in this report cover the two-year period from June 1,1935 , to June 1, 1937, and are isuned as a progress statement of the five-year study.

\section{Description of the Jackson Demonstration Area}

\section{Location}

The Jackson area embories a large portion of Jackson County including practically all of its agricultural area, with the exception of the river bottoms in the northwestern part (Fig. 1). 'This Soil Conservation Service demonstration area is known in the Service as S.C.S. W.Va.-6, with headquarters at Ripley. ${ }^{2}$ The work in this area is administered by the staff of Project I at Spencer. West Virginia where central administration is maintained for the project and two cainp areas.

The location of the 187 farms studied in the Jackson Area is shown in Fig. 1. They are well distributed throughout the immediate area now served by the demonstration work. Farms studied include those placed under cooperative agreements with the Soil Conservation Service, together with farms not under agreements. The latter will serve as a check and also denote the tendency for the average farmer to acquire and use the practices employed by farms on which agreements and plans have been definitely worked out by the Service.

\section{Topography}

The topography of the land in farms is not unlike that in many other sections of the state. More than half of the land included in this study has a slope of 25 to $40 \%$, and about one-fifth of the area has a slope of more than $40 \%$. The remainder is about equally divided

2This demonstrational work in soil conservation is accomplished with the aid of labor and other assistance made available by the Civilian Conservation Corps. 
between slope classes of $0-12 \%$ and $12-25 \% .^{3}$ At present the latter classes constitute the majority of the crop land, such land being locaterl along the numerous streams of the area and in the narrow valleys. In the past, much of the land of $40 \%$ slope or less was used for general farm production; but because of a great decrease in the productivity

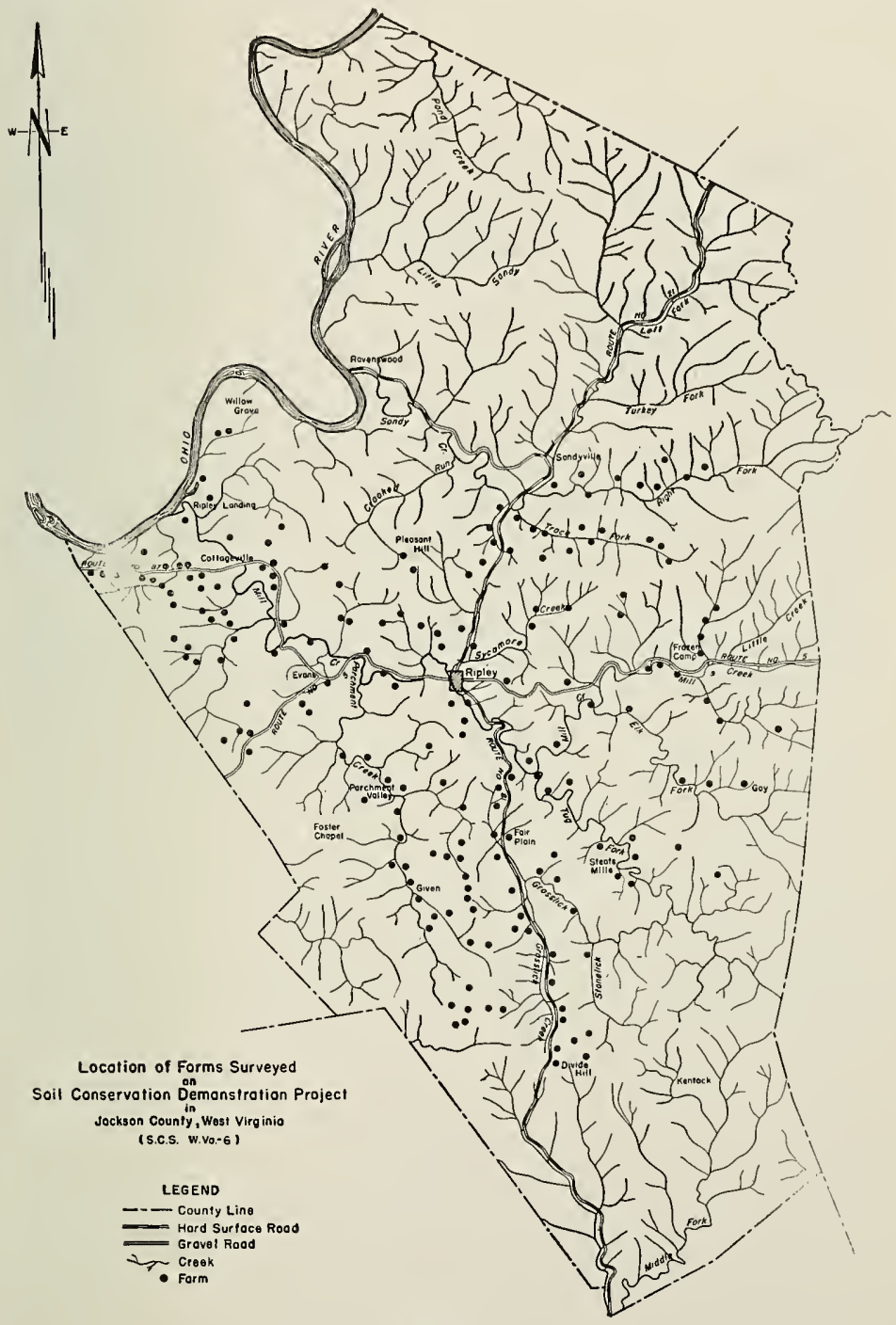

FIg. 1

3Pohlman, G. G.. Land Classification in West Virginia, Bul. 294, West Virrinia Agricultural Experiment Station, November, 1937, 
of this steep land, much of it has been abandoned or has reverted to pasture. Erosion is very severe on the steeper slopes when they are cultivated and planted to annual grains or row crops. (Fig. 2.)

The Ohio River section of Jackson County represents the principal portion of the land of lesser slopes. The southeastern part of the county is very steep and rough, embodying little farming of any consequence. The elevation of the area ranges from about $580 \mathrm{ft}$. at the Ohio River to possibly $700 \mathrm{ft}$. in the eastern portion.

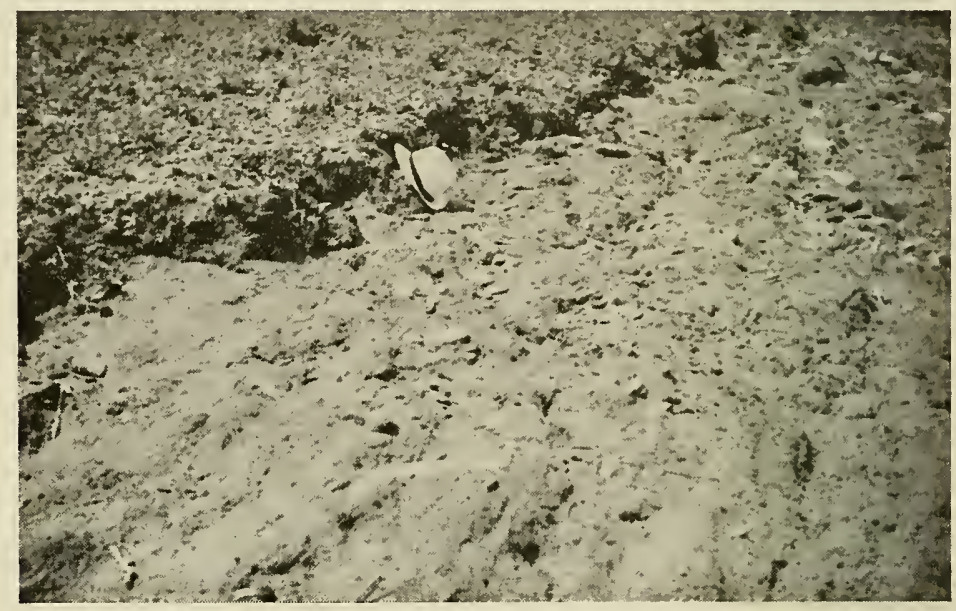

FIG. 2-Stream overflow in the narrow valley earried away more than nine inches of topsoil from this soybean field

Soils ${ }^{4}$

There are about 19 distinct types of soil in the Jackson area. These types represent three different physiographic regions: i. e., flood plains, terraces, and uplands.

The flood plains, or first bottoms, are found principally along the Ohio River. The alluvial deposits of the river have produced these soils. They are subject to little or no erosion. However, inundation by overflowing streams is a frequent occurrence, and deposition of silt and gravel often occurs. (Fig. 3.)

The terraces, or second bottoms, occur along the principal streams, draining into the Ohio. They are derived primarily from the higher lying soils and have been deposited along the streams and lesser slopes by washing: These are the most important crop-producing soils in the area. These lowland soils have a decidedly silty clay texture. They are inclined to be rather sticky, and in some places poorly drained. Because of slow percolation of free water into these soils, sheet erosion causes serious damage.

4W. J. Latimer and C. N. Mooney, Soil Survey, Jackson County, U, S. Dept. of Agriculture, 1911. 
The upland soils constitute about three-fourths of the entire area. They are generally steep, erosion is extremely active on them, and "slips" are common. In the past these upland soils have produced well and were farmed rather intensively despite their slope. Little effort, however, was given to management practices that wottid minimize erosion. In many instances they have been abandoned, and undesirable brush and weeds are the only cover.

The Reconnaissance Survey of West Virginia classes the majority of this area as having severe sheet erosion and frequent gullies. This denotes a serious handicap to agriculture.

\section{Climate}

The climate of this area is mild. Neither hot nor cold periods are of long duration. Only slight variations in mean temperature were reported for the two years, except during the winter months. During the months of December, January, and February, 1936, the temperature ranged 10 to 15 degrees higher than was true of the same period in 1935.

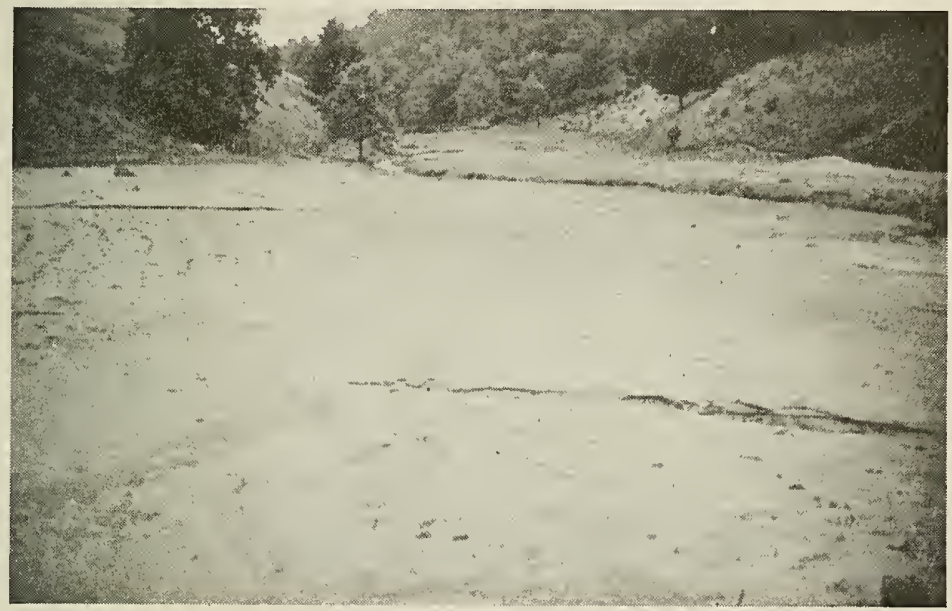

FIG. 3-Soil and ground washed from above was deposited on this corn field. Land is temporarily or permanently destroyed

During the same period precipitation was about seven inches above normal, causing many disastrous floods and much erosion on igricultural lands. The spring and summer growing scason of 1936 was very dry. In fact the total precipitation for the latter year was about six inches less than during 1935. The average annual rainfall or the area is about 40 inches.

The irregularity of rainfall, combined with other factors, constitutes a serious handicap to erosion-control measures. Very heavy ainfall for short periods causes much damage to land not fully protected against this hazard. Long periods of droughty weather ren- 
der the topsoil very dry. It then is removed easily from the relatively impervious steep slopes by torrential rainfall.

\section{Land Classification}

On the basis of soil, climatic, economic, and social factors, the land of the county has been divided into classes according to the influence of the various factors on the use and value of land for agricultural purposes.

Very little land in fackson County is classified in the three better land classes (Table 1). More than one-half of the area of the county is rated as poor crop land and average pasture land. From this it appears that the land generally should be devoted to pasture and forage crops with the possible exception of small areas of alluvial and terrace soils.

TABLE 1-Proportion of land of Jachson County in various classes for agricultura थ $s e^{1}$

\begin{tabular}{|c|c|c|}
\hline & Class and description & $\begin{array}{c}\text { Percentage in } \\
\text { each class }\end{array}$ \\
\hline $\begin{array}{c}\text { I } \\
\text { II } \\
\text { III } \\
\text { IV } \\
\text { V } \\
\text { VI } \\
\text { VII } \\
\text { VIII } \\
\text { Total }\end{array}$ & $\begin{array}{l}\text { - Superior crop land } \\
\text { - Good crop land } \\
\text { - Average crop land } \\
\text { - Below average crop land - good pasture } \\
\text { - Inferior crop land - average pasture } \\
\text { - Submarginal land } \\
\text { - Forest land } \\
\text {-Urban and industrial land }\end{array}$ & $\begin{array}{r}1.63 \\
1.51 \\
1.82 \\
19.67 \\
56.46 \\
18.56 \\
.3 \dot{35} \\
100.00\end{array}$ \\
\hline
\end{tabular}

${ }^{1}$ Pohlman, G. G., Land Classification in West Virginia, Bul. 2\$4, West Virginis Agricultural Experiment Station, 1937.

\section{Social Aspects of Farm Families}

The paved north-south route and the gravel east-west route con stitute the major improved roads serving the area as a whole. Th, remainder of the roads serving the various communities are ordinary clay-base roads. Two-thirds of the farms are located on clay roads which become muddy and sometimes impassable during long rain! periods. Only $12 \%$ of the farms studied were located on paved roads while $20 \%$ were on gravel-surfaced roads.

The secondary schools are rather distant from some commun ities, especially for those families situated on the poor type of roads Ordinarily the community institutions are within reasonable dis tance of most localities.

\section{Age of Farmers}

The age of farmers in the Jackson area, as in many rural area: in West Virginia, is high. The average age of farm operators in $193:$ was 54 .

According to the distribution of ages, $47 \%$ of all farmers wert over 55 years of age, and $24 \%$ were over 65 . Very few younger men appeared to be interested in farming as a life work, Many young 
men from the faims obtain employment in the industries of this and other states where cash wages seem to be more attractive than the livelihood afforded by the farm.

\section{Background of Farmers}

Practically all the farmers surveyed were descendants from older residents of the same areas. Ninety-seven percent were born on farms.

A majority seem to have moved about considerably. Fifty-five percent had moved from farm to farm an average of 2.7 times before acquiring their present home. Almost one-third of all farmers had lived in town at least once during their life. Although data are not arailable to substantiate directly a motive for these moves to town, it can reasonably be assumed that many of these families obtained their livelihood from industrial work in earlier life. More than $50 \%$ of the farm operators had worked at laboring jobs for an average period of 12 years before becoming farmers. Others held jobs either before becoming farmers or had ceased farming for a period and had engaged in other work.

Approximately $30 \%$ had been tenants for a comparatively short time before becoming owner-operators. The usual term of tenancy did not exceed five years. The average term of ownership for farmers reporting these data was 27 years.

\section{Farm Families}

At the time of the survey, there were 4.5 persons in the average farm home including children, relatives, and others. About $8 \%$ of the farm children born per family had died before 1935 .

A majority of the sons had left the farm for work of other types. However, $43 \%$ were farming either on the home farm or elsewincre. This proportion was greater than was the case in some other areas of the state.

Fewer of the daughters had remained on the home farms than was true of the sons. However, more than $50 \%$ of all married daughters had married farmers and were living in the lome community or elsewhere on farms. Like most other present-day rural areas that are in proximity to some business or industrial areas, the younger single women had found employment away from the farms.

Only a small percentage of the homes had utility conveniences, and many could not afford automobiles. The farmsteads were equipped with a minimum of machinery.

Most communities were completely rural and many families led a rather frugal existence, possessing few of the modern conveniences and enjoying a limited portion of the goods of society.

\section{Conditions Affecting Social and Economic Planning}

A planning program purporting to establish greater stability and permanency to the agricultural livelihood of this area must face the 
following facts: (1) The location of many of these people on poor roads, relatively remote from market, will make progress slow, especially with keen competition from areas more advantageously located. (2) The age of farmers determines to a large extent their willingness to adopt new, improved methods of farming. The fact that farmers in this area average 54 years of age signifies that many of them are probably not intensely interested in expending much cash to establish a long-time improvement program.

(3) This condition is further substantiated by the fact that a majority of the children and younger people have sought a livelihood away from the farms. Thus neither the young nor the old are intensely interester in the future improvement of agriculture in the area. (4) Many of these people became farmers not by choice but by necessity. It is evident that many became farmers after spending their most productive years at industrial work. Their lack of training and experience undoubtedly has had the effect of producing a less stable type of agriculture. A lack of care and attention that should have been given the land has probably accounted for many of the land problems encountered at this time. (5) Speculation in gas and oil underlying most of the area has led some to depend and wait on expected wealth from these sources. In the meantime the land has been neglected.

\section{Agricultural Production}

The following description of the agriculture in the Jackson area is intended to portray in detail the basic sources of income and the plan of farm organization. Data have been obtained for two successive years, 1935 and 1936 . The data for 1935 represent conditions before being disturbed by the program of conservation. The data for the following year do not show significant changes, since the demonstration work had not progressed sufficiently during the first year. However, certain tendencies are already in evidence and will be pointed out. In addition, certain conditions will be described that have a direct relationship to the program of soil conservation which has been established. The following description of farming should be valuable in understanding the conditions within this area, which is fairly representative of a large portion of West Virginia, and the relationship of these conditions to the planning of a conservation program.

Of the 34,000 acres included in the 187 farms, all except $13 \%$ were owner-operated. Slightly more land was rented in 1936 than during the preceding year, accounting principally for the increase of approximately three acres in the average size of farms.

\section{Size of Farms}

The average size of the 187 farms was 179 acres in 1935 and 182 in 1936. This is larger than the average of 98 acres in the county, and 90 acres per farm in the state as a whole. The farms ranged in 
TABLE 2-Distribution of farms according to size in Jackson area, 1935-36

\begin{tabular}{c|cc|c|c}
\hline \multirow{2}{*}{$\begin{array}{c}\text { Size class } \\
\text { (Acres) }\end{array}$} & \multicolumn{3}{|c|}{ Number } & \multicolumn{2}{c}{$\begin{array}{c}\text { Percentage in } \\
\text { each class }\end{array}$} \\
\cline { 2 - 6 } & 1935 & 1936 & 1935 & 1936 \\
\hline $1-50$ & 19 & 17 & 10.2 & 9.1 \\
$51-100$ & 40 & 45 & 21.4 & 24.1 \\
$101-150$ & 41 & 38 & 21.9 & 20.3 \\
$151-200$ & 24 & 26 & 12.8 & 13.9 \\
$201-250$ & 29 & 24 & 15.5 & 12.8 \\
$251-300$ & 12 & 11 & 6.4 & 13.9 \\
Over 300 & 22 & 26 & 11.8 & 100.0 \\
Total & 187 & 187 & 100.0 & \\
\hline
\end{tabular}

size from less than 50 acres to more than 300 acres, and were rather evenly distributed within this range. Less than one-fourth of all farms fell within any one size class as shown in Table 2. However, $50 \%$ of all farms were under 150 acres in size, and less than $20 \%$ were over 250 acres.

\section{Investment}

The average investment for the years 1935 and 1936 was approximately $\$ 7000$ per farm. The increase noted during the two-year period was primarily a result of a general increase in the value of livestock. There was also a slight increase due to the excess of improvements over depreciation. During the depression years few repairs were made. Hence, necessary repairs and improvements exceeded in value the anntal depreciation charged against the beginning inventory.

The percentage of the total investment represented by the respective items of farm valuation is presented in Table 3 . Half of the total investment of these farmers was in land, while slightly more than one-fourth was in buildings. The remaining one-fourth was in livestock, machinery, and supplies.

TABLE 3-Proportion of total investment in various items on 187 farms in Jackson $a^{\prime} e a^{1}$

\begin{tabular}{|c|c|c|c|c|}
\hline \multirow{2}{*}{ Property } & \multicolumn{2}{|c|}{$\begin{array}{l}\text { Investment } \\
\text { per farm }\end{array}$} & \multicolumn{2}{|c|}{$\begin{array}{l}\text { Percentage of total } \\
\text { investment }\end{array}$} \\
\hline & $1935^{2}$ & 1936 & $1935^{2}$ & 1936 \\
\hline Land and fences & $\$ 3,537$ & $\$ 3,545$ & 51.9 & 51.0 \\
\hline Dwelling & & 1,041 & $\ldots$ & 15.0 \\
\hline Barn & 1,951 & 557 & 28.7 & 8.0 \\
\hline Other buildings $\quad$ J & & 339 & & 4.9 \\
\hline Total real estate & $\$ 5,488$ & $\$ 5,482$ & 80.6 & 78.9 \\
\hline Livestock & 983 & 1,125 & 14.4 & 16.2 \\
\hline Feed and supplies & 35 & 53 & .5 & .7 \\
\hline Machinery and equipment & 301 & 285 & 4.5 & 4.2 \\
\hline Total & $\$ 6,807$ & $\$ 6,945$ & 100.0 & 100.0 \\
\hline
\end{tabular}

1170 farmers possessed investment in real estate, at an average value of
$\$ 6,056$.

2Valuations for buildings were not itemized for 1935 . 
The sum of $\$ 300$ appears small for the total per-farm valiation on machinery especially when a large percentage of the value was in automobiles, a relatively non-profluctive item of equipment. Farm machinery has depreciated markedly and was in a poor state of repair. In general, it has receiverl poor care and has not been replaced at regular intervals. Consequently the majority of the farm machinery found on these farms was old and of low value.

The investment in livestock appeared to be ahove average for this section of the State, and considering the past low-producing years most farms were moderately well stocked. However, many of the smaller farms were devoid of livestock above that necessary for a self-sufficing livelihood.

Farm dwellings constituter $5+\%$ of the total investment in real improvements while the barns and other buildings constituted about $46 \%$ of the total. In general, it appeared that much of the investment was in the farm as a home rather than a business unit. A large portion of the total capital of any business in non-productive equipment necessarily reduces the cash income-producing ability.

TABLE 4-Bottom land, crops on slopes, and area burned over annually, Jackson area, 1935

\begin{tabular}{l|c|cccc}
\hline \multicolumn{1}{c}{ Items } & $\begin{array}{c}\text { Total } \\
\text { acres }\end{array}$ & $\begin{array}{c}\text { Percentage } \\
\text { of total } \\
\text { land area }\end{array}$ & $\begin{array}{c}\text { Number } \\
\text { of farms } \\
\text { reporting }\end{array}$ & $\begin{array}{c}\text { Acres } \\
\text { perfarm } \\
\text { reporting }\end{array}$ & $\begin{array}{c}\text { Acres } \\
\text { fer farm } \\
\text { (all farms) }\end{array}$ \\
\hline Bottom land & 3,609 & 10.8 & 149 & 24.2 & 19.3 \\
Crops on slopes & 3,075 & $9.2^{2}$ & 130 & 23.7 & 16.4 \\
Acres burned & 681 & $\ldots{ }^{2}$ & 37 & 18.4 & 3.6 \\
\hline
\end{tabular}

${ }^{1}$ Crops on slopes represent $47.1 \%$ of all crop land.

${ }^{2}$ Acres burned over in 1935 represent $3.4 \%$ of area in permanent pasture.

THE CHARACTER OF FARMING

\section{Land Use}

To a greater extent than any other single factor, the use of land probably reflects its ability to maintain a population. Land use has, to an appreciable extent, determined the present economic status of this area and will affect materially the future of the area.

Approximately $11 \%$ of the total land in farms was bottom land and terraces. This percentage allowed an average of about 24 acres of bottom land per farm for the 149 farms reporting this item. The bottom land described above was not necessarily first hottom, but a part of it was terrace soils which were not necessarily tree from slope.

Farmers in this area for several years had followed the practice of burning their pastures. Many stater that the practice has since been abandoned. The motive for this practice was to clear the land of briers, tough grasses, and debris. In 1935, 37 farmers burned an average of 18 acres per farm, a total of 681 acres. This acreage represented about $3.4 \%$ of all pasture land. Undoubtedly such a practice is conducive to erosion. The land is cleared of its organic residue and left without a covering of absorptive material that would ordinarily 
TABLE 5-Land use of 187 farms in Jackson area, 1935-36

\begin{tabular}{|c|c|c|c|c|c|c|}
\hline \multirow{2}{*}{ Land use } & \multicolumn{2}{|c|}{$\begin{array}{c}\text { Acres } \\
\text { per farm }\end{array}$} & \multicolumn{2}{|c|}{$\begin{array}{c}\text { Percentage } \\
\text { of all land }\end{array}$} & \multicolumn{2}{|c|}{$\begin{array}{c}\text { Number farms } \\
\text { reporting }\end{array}$} \\
\hline & 1935 & 1936 & 1935 & 1936 & 1935 & 1936 \\
\hline Crops & 34.9 & 35.2 & 19.5 & 19.3 & 187 & $186^{1}$ \\
\hline Permanent pasture & 107.9 & 111.9 & 60.8 & 61.5 & 183 & $180 ; 2$ \\
\hline Woods pastured & 24.0 & 21.6 & 13.4 & 11.8 & 156 & 146 \\
\hline Woods not pastured & 6.4 & 9.9 & 3.6 & 5.2 & 54 & 71 \\
\hline Other land & 3.5 & 1.1 & 2.0 & .9 & 48 & 20 \\
\hline Farmstead, roads, etc. & 2.1 & 2.3 & 1.2 & 1.9 & 187 & 187 \\
\hline 'T'otal & 178.8 & 182.0 & 100.0 & 100.0 & 187 & 187 \\
\hline
\end{tabular}

TOne falmer rented out all crop land.

?One self-sufficing farmer share-rented only crop land as a farm.

serve as an agent for conducting water into the soil. Surface water is permitted to rum off at a rapid rate and to carry quantities of soil with it. (Tables 4 and 5.)

About $19 \%$ of all land was devoted to crops while approximately $60 \%$ was permanent pasture. The large percentage of tarm area in pasture immediately suggests a grazing type of agriculture. About $16 \%$ of all land in farms was woodland, three-fourths of which was pastured. The remainder of the land in farms was classified as other land and as farmsteads. (Fig. 4.)

The only changes in land use that were significant in the data for 1936, compared with the preceding year, were as follows:

(a) increase in pasture land per farm, accomplished generally by renting more land;

(b) decrease in woods pastured and resulting increase in woods not pastured;

(c) decrease in idle land, accomplished by planting to trees and by using all land possible.

Practically no change in acreage of crop land was noted, but tlie

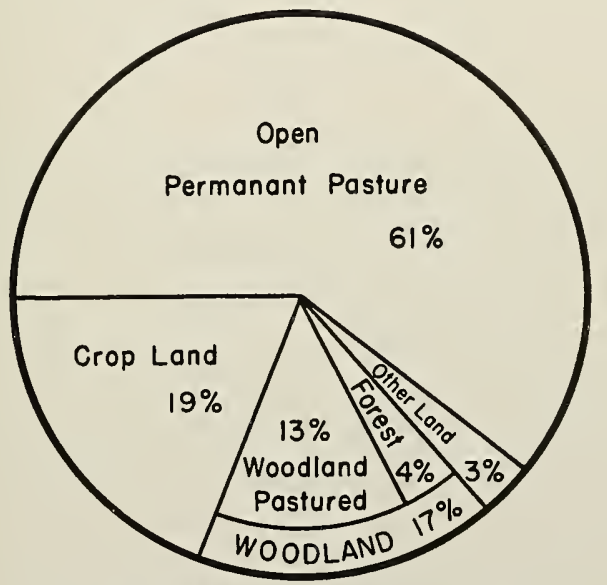

Fig. 4-Use of land in Jackson County area 
tendency appeared to be toward an increase coordinate with the general tendency to ase all land possible, some of which had been idle in prior years.

\section{Farm Praclices}

Because of the rough topography of the land very few farmer: use modern cultivating and harvesting equipment. Much of the grain is still cut by a clrop reaper or cradle and is bunched and tied by hand. Many other jobs facilitated by machinery in other areas are accomplished by hand labor here.

During the depression years 1930 to 1934 , very little fertilizer and lime were applied. In fact, lime las never been used extensively by these farmers in spite of a rapidly growing need. The data in Table 6 indicate that the use of fertilizer and lime is becoming more general. One-fourth more farmers used some commercial fertilizer in 1936 than in 1935, and $50 \%$ more acres were treated in the latter year. The tendency in 1936 was to treat more acres with slightly less fertilizer per acre. It may be noted that about $14 \%$ of all crop land was treaterl with fertilizer.

The number of farmers using lime tripled in the latter year over 1935. The average acreage treated per farm increased $400 \%$, accompanied by a slight increase in the rate of application per acre. This denotes a definite trend toward soil-building practices that liave been seriously lacking heretofore.

TABLE 6-Fertilizer, lime, and manure used by 187 farms in Jackson area, 1935-36

\begin{tabular}{|c|c|c|c|c|c|c|}
\hline \multirow{2}{*}{ Items } & \multicolumn{2}{|c|}{$\begin{array}{l}\text { Acres treated } \\
\text { per farm }\end{array}$} & \multicolumn{2}{|c|}{$\begin{array}{l}\text { Amount used } \\
\text { per acre }\end{array}$} & \multicolumn{2}{|c|}{$\begin{array}{l}\text { Number report- } \\
\text { ing use }\end{array}$} \\
\hline & 1935 & 1936 & 1935 & 1936 & 1935 & 1936 \\
\hline $\begin{array}{l}\text { Commercial fertilizer } \\
\text { Lime } \\
\text { Manure }\end{array}$ & $\begin{array}{r}4.2 \\
5.5 \\
5.3\end{array}$ & $\begin{array}{l}6.2 \\
2.2 \\
5.4\end{array}$ & $\begin{array}{l}262 \mathrm{lbs} . \\
2.3 \mathrm{~T} . \\
6.9 \mathrm{~T} .\end{array}$ & $\begin{array}{l}229 \mathrm{lbs} . \\
2.5 \mathrm{~T} . \\
5.5 \mathrm{~T} .\end{array}$ & $\begin{array}{r}81 \\
12 \\
152\end{array}$ & $\begin{array}{r}109 \\
33 \\
179\end{array}$ \\
\hline
\end{tabular}

\section{CROPS}

The major crops grown in the Jackson area during 1935 were hay, corn, and wheat. Corn and hay represented the feed crops for a livestock type of farming, while wheat is a remnant of a cash grain type of farming which has almost vanished. Wheat now furnishes the farms with some small grain feed. (Table 7.)

Hay occupied $61 \%$ of all crop land in 1935. About $85 \%$ of the total acreage in hay was mixed clover and timothy. The remainder was divided between alfalfa, soybeans, wheat hay, and oat hay. In 1936 the hay acreage increased about $3 \%$ primarily because of the introduction of lespedeza as a forage crop and the growing of more alfalfa for dairy feed.

Corn is the second most important crop from the standpoint of acreage. It is important from the standpoint of maintaining livc- 
TABLE 7-Acreage of crops on 187 farms in Jackson area, 1935-36

\begin{tabular}{|c|c|c|c|c|c|c|}
\hline \multirow{2}{*}{ Crop } & \multicolumn{2}{|c|}{$\begin{array}{l}\text { Acres grown } \\
\text { per farm }\end{array}$} & \multicolumn{2}{|c|}{$\begin{array}{l}\text { 'ercentage of } \\
\text { all crop land }\end{array}$} & \multicolumn{2}{|c|}{$\begin{array}{c}\text { Number furms } \\
\text { reporting }\end{array}$} \\
\hline & 1935 & 1936 & 1935 & 19.36 & 1935 & 1936 \\
\hline $\begin{array}{l}\text { Coln-grain } \\
\text { Wheat } \\
\text { Oats } \\
\text { Mixed hay } \\
\text { Alfalfa } \\
\text { Soybeans } \\
\text { Wheat has } \\
\text { Oat hay } \\
\text { Lespedez: } \\
\text { Potatoes } \\
\text { lruck } \\
\text { Orcharr } \\
\text { Other }\end{array}$ & $\begin{array}{r}8.3 \\
.4 \\
3.0 \\
.1 \\
18.6 \\
.6 \\
1.5 \\
.7 \\
.5 \\
. .1 \\
.8 \\
.9 \\
.4\end{array}$ & $\begin{array}{r}7.0 \\
.2 \\
3.4 \\
17.5 \\
.9 \\
1.5 \\
.7 \\
.9 \\
1.2 \\
.1 \\
.9 \\
1.5 \\
.3\end{array}$ & $\begin{array}{r}23.1 \\
1.1 \\
8.4 \\
.3 \\
51.8 \\
1.7 \\
4.2 \\
1.9 \\
1.4 \\
\ldots \\
. .3 \\
2.2 \\
2.5 \\
1.1\end{array}$ & $\begin{array}{r}19.3 \\
.91 \\
9.4 \\
18.5 \\
2.5 \\
1.1 \\
2.0 \\
2.5 \\
3.3 \\
. .3 \\
2.5 \\
4.1 \\
.9\end{array}$ & $\begin{array}{r}169 \\
6 \\
67 \\
4 \\
171 \\
11 \\
43 \\
19 \\
15 \\
79 \\
154 \\
43 \\
14\end{array}$ & $\begin{array}{r}160 \\
4 \\
70 \\
168 \\
20 \\
48 \\
18 \\
29 \\
35 \\
61 \\
185 \\
99 \\
12\end{array}$ \\
\hline Total & 35.9 & 36.1 & 100.0 & 100.0 & 187 & 187 \\
\hline
\end{tabular}

stock as well as food for home consumption. The farms surveyed in 1935 produced 8.7 acres of corn per farm, or about $24 \%$ of all crop land. In 1936 there appeared to be a definite tendency avay from this comparatively high corn acreage. The average acreage grown per farm in this latter year was 1.5 acres less than in 1935 . This seems to be a desirable tendency since many farms do not have bottom or $o$ her land suitable for growing large acreages of corn withont danger of serious erosion. If corn acreage can be reduced to a minimum by substituting erosion-resistant crops in its place, the productivity of much of the sloping land of the area may be prolonged.

Wheat occupied $8.4 \%$ of all crop land in 1935 and increased slightly to $9.4 \%$ in 1936 . Practically no other small grains were grown in the area except some oats for hay. Wheat is sometines cut for hay, particularly in drought years. Truck and fruit are not grown to any great extent. Hence they occupy a very small percentage of the total land area of these farms.

\section{Erosion Resistance of Crops}

In reviewing the soils and topography of the Jacksnn area it was pointed out that the greater part of the area was subject to serious erosion. Because of the steepness of land and the heavy precipitation it is desirable wherever possible to grow crops that will protect the soil against erosion and at the same time build up the plant food content for maintaining crop production. (Fig. 5.)

In Table 8 the crops have been classified according to their ability to resist erosion. One of the primary objectives of the soil-conservation program is to encourage farmers to fit into their farm organization those crops that will resist erosion, thereby replacing some of the non-erosion-resisting crops now grown.

The data indicate that $56 \%$ of all crops grown in 1935 were erosion-resistant, consisting principally of forage crops. There was 


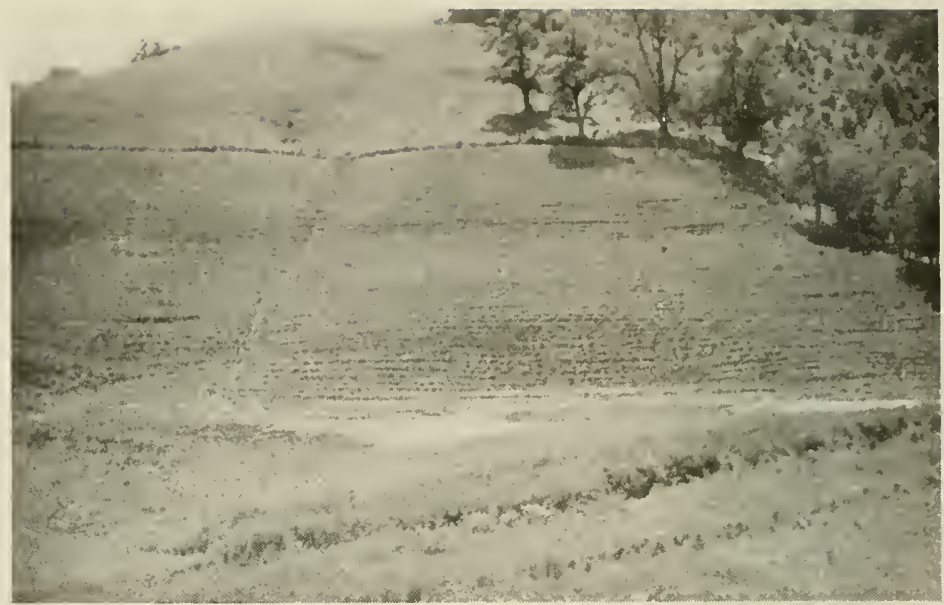

FIG. 5-Land having slopes of 25 to $t 0$ perecnt is cultivated continuously without the use of erosion-control measures. Sheet and gully erosion are extremely active

an increase of about $2.5 \%$ in erosion-resistant crops in the followin year. The introduction of lespedeza and the encouragement give to the growing of alfalfa is partially, if not entirely, responsible fo this increase. On the other hand those crops, principally cor offering practically no resistance to erosion, decreased in acreage pe farm by about 1.4 acres. The semi-erosion-resistant small grains in creased slightly in 1936.

In general it appears that during future years there will be a mo1 decided shift to erosion-resistant crops if the farmers are ahle to $f$ them into their production program advantageously. However, tl high cost of lime, fertilizer, and seed for legumes has made suc changes almost imposible with some farmers during the past yea The change must be gradual if accepted on the small farms. whic are generally the ones most in need of a change to erosion-resistat crops.

\section{Crop Yields}

Crop yields were comparatively low during 1936. The drought conditions during the year reduced the hay yields more than 50\%

TABLE 8-Character of crops grown with respect to comparative resistance to erosio

\begin{tabular}{l|r|r|r|r}
\hline \multirow{2}{*}{ Type of crops } & \multicolumn{2}{c}{$\begin{array}{c}\text { Acreage } \\
\text { per farm }\end{array}$} & \multicolumn{2}{c}{$\begin{array}{c}\text { Percentage of } \\
\text { all crop land }\end{array}$} \\
\cline { 2 - 5 } & 1935 & 1936 & 1935 & 1936 \\
\hline Erosion-resistant & 20.1 & 21.1 & 55.9 & 58.4 \\
Semi-erosion-resistant & 6.2 & 6.8 & 17.3 & 18.8 \\
Noln-erosion-resistant & 9.6 & 8.2 & 26.8 & 22.8 \\
Total & 35.9 & 36.1 & 100.0 & 100.0 \\
\hline
\end{tabular}


reating a scarcity of forage during the following winter. l'astures vere very short during the summer. Wheat yields were about $9 \%$ uver than in 1935. (Table 9.)

The yields of corn were very low for both years, being less than wo-thirds of the state average. These low yiclds indicate a necd for general improvement in soil productivity. Other grain crop yields ilso were low during both years. There have been (wo handicaps n producing grain crops in this area: (1) drought hat frequnently lestroyed crops during the last decade; and (2) the crops grown on ottom soils in the narrow bettoms are frequently fooded during he growing seasons, which reduces yields materially.

An interesting comparison can be seen in the variation in yielils of the several hay crops. Oat hay generally is a low producer, yet a ew farmors continue to raise it. Wheat is seldom cut for hay except vhen it is needed more for forage than for grain, or in cases when its ralue as grain is destroyed by climatic conditions. Although alfalfa vas raised by a comparatively few farmers, the yields of this crop were romising in comparison with the low yields of mixed hays. It is rue, however, that crop yields probably could be increased appreiably by raising more of perennial legumes in place of the grain an!1 imothy hay now grown.

[ABLE 9-Fields of major crops grown in Jackson area

\begin{tabular}{|c|c|c|c|}
\hline \multirow{2}{*}{ Crop } & & \multicolumn{2}{|c|}{ Yield per acre } \\
\hline & & 1935 & 1936 \\
\hline $\begin{array}{l}\text { Win } \\
\text { Wheat } \\
\text { Mixed hay } \\
\text { tlfalfa } \\
\text { Wheat hay } \\
\text { Jat hay } \\
\text { joybeans } \\
\text { espedeza }\end{array}$ & $\begin{array}{l}\text { ( bu.) } \\
\text { ( bu.) } \\
(\mathrm{T} .) \\
(\mathrm{T} .) \\
(\mathrm{T} .) \\
(\mathrm{T} .) \\
\text { (T.) }\end{array}$ & $\begin{array}{r}16.6 \\
11.0 \\
1.2 \\
2.8 \\
2.6 \\
1.2 \\
1.9 \\
\ldots .\end{array}$ & $\begin{array}{r}17.6 \\
10.0 \\
.6 \\
1.0 \\
.8 \\
.6 \\
1.2 \\
\ldots .1\end{array}$ \\
\hline
\end{tabular}

${ }^{1}$ All new plantings.

\section{Pasture Capacities}

The yield of pastures in this area is of equal or greater importance to farm income than crop yields when considered in connection with the predominant livestock type of farming. Unfortunately a failacious opinion has existed here as well as elsewhere in regard to the growing of pastures. It has been assumed, too generally, that pastures were a spontaneous product of nature. Consecpuently they have received little care and often have deteriorated in quality. Sheet erosion and drought have practically destroyed large acreages as a result of neglectful management. More care in establishing and utilizing pastures is needed if their maximum usefulness is to be secured. (Fig. 6.)

According to a recent survey of pasture conditions in Jackson

iPierre, W. H.. et al. West Virginia Pastures, West Virginia Agricultural Experiment Station Bul. 2so. 1937. 


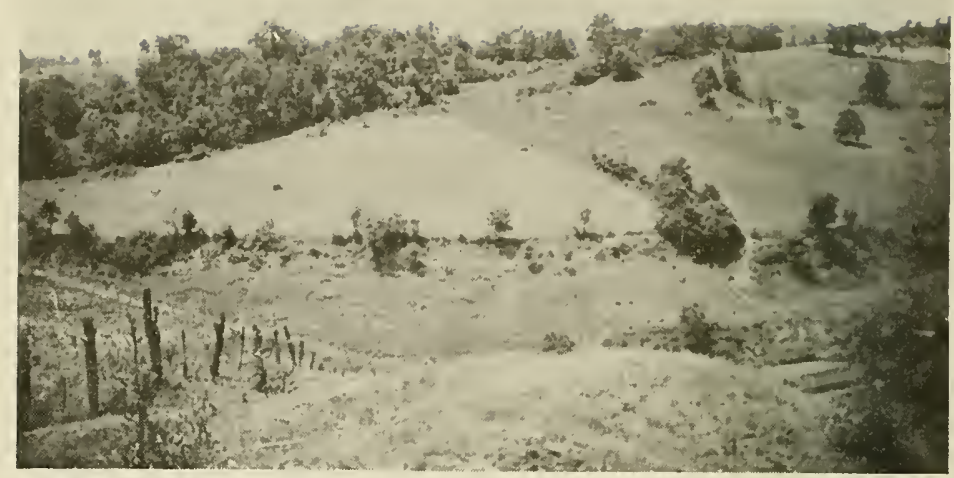

FIg. 6-The productive life of steep land that is rultivated without regard to erosion control is short. Soon much of it is abandoned to low-quality pasture and brush

County, they were of very low quality. Only $13.5 \%$ of the total pasture grasses was desirable, compared to $47 \%$ in two eastern counties and $24 \%$ as an average for the state. Approximately $92 \%$ of all pastures was in need of an average of at least one ton of lime per acre, and $97 \%$ was in need of phosphorus. It was estimated that $36 \%$ of all pasture land was not worth improving. In general, this elintinates more than a third of the pasture land. About $77 \%$ of all pastures included in the survey was classed as poor.

The acreage of pasture available per farm was above average for the state. In 1935 there were 132 acres of available pasture area per farm, and slightly more in 1936. This allowed about 7.6 acres per animal unit if the wooded pasture is included, or 6.3 acres if woodland is excluded. From observation it is known that the arerage pasturecarrying capacity was low during both years. The logical conclusion is that if pastures were improved, more livestock could be maintained at a higher rate of return to the farmers, while the annual cost of improving would be comparatively low. (Table 10.)

\section{Crop Sales}

On most of the farms crop sales are only supplementary to the TABLE 10-Pasture available on 187 farms in Jackson area

\begin{tabular}{|c|c|c|c|c|}
\hline \multirow{2}{*}{ Kind } & \multicolumn{2}{|c|}{$\begin{array}{l}\text { Acres } \\
\text { per farn }\end{array}$} & \multicolumn{2}{|c|}{$\begin{array}{c}\text { Acres per animal } \\
\text { unit pastured }\end{array}$} \\
\hline & 1935 & 1936 & 1935 & 1936 \\
\hline $\begin{array}{l}\text { Oren nermanent pasture } \\
\text { Wooded pasture }\end{array}$ & $\begin{array}{r}107.9 \\
24.0\end{array}$ & $\begin{array}{r}111.9 \\
21.6\end{array}$ & $\begin{array}{l}6.2 \\
1.4\end{array}$ & $\begin{array}{l}6.4 \\
1.2\end{array}$ \\
\hline Total & 131.9 & 133.5 & 7.6 & 7.6 \\
\hline
\end{tabular}


TABLE 11-Crop sales of 187 farms in Jackson area, 1935-36

\begin{tabular}{|c|c|c|c|c|c|c|c|}
\hline \multirow{2}{*}{ Sold } & & \multicolumn{2}{|c|}{$\begin{array}{c}\text { Prices received } \\
\text { per unit }\end{array}$} & \multicolumn{2}{|c|}{$\begin{array}{c}\text { Value } \\
\text { per farm }\end{array}$} & \multicolumn{2}{|c|}{$\begin{array}{c}\text { Number of } \\
\text { farms reporting }\end{array}$} \\
\hline & & 1935 & 1936 & 1935 & 1936 & 1935 & 1936 \\
\hline $\begin{array}{l}\text { Corn } \\
\text { Wheat }\end{array}$ & $\begin{array}{l}\text { (bu.) } \\
\text { (bu.) }\end{array}$ & $\begin{array}{ll}\$ & .81 \\
& .89\end{array}$ & $\begin{array}{l}1.14 \\
1.20\end{array}$ & $\begin{array}{r}\$ 7.37 \\
4.20\end{array}$ & $\begin{array}{r}\$ 13.83 \\
4.89\end{array}$ & $\begin{array}{r}19 \\
6\end{array}$ & $\begin{array}{l}21 \\
10\end{array}$ \\
\hline $\begin{array}{l}\text { Oats } \\
\text { Mixed hay }\end{array}$ & (bu.) & 10.68 & 15.64 & $\because .74$ & $\dddot{602}$ & 15 & 17 \\
\hline Alfalfa & (T.) & 14.50 & 21.58 & b. 20 & 2.77 & 2 & 3 \\
\hline Straw & (T.) & $\cdots$ & $\cdots$ & 2.69 & 4.63 & 4 & 11 \\
\hline Potatoes & (bu.) & .64 & 1.15 & 2.05 & 1.25 & 6 & 6 \\
\hline Truck & & $\ldots$ & $\cdots$ & 7.09 & 11.10 & 11 & 17 \\
\hline Fruits & & $\cdots$ & $\ldots$ & 22.91 & 9.85 & 8 & 5 \\
\hline Other & & $\cdots$ & $\cdots$ & 1.20 & .91 & 1 & 2 \\
\hline Total & & & $\cdots$ & $\$ 58.45$ & $\$ 55.25$ & 47 & 52 \\
\hline
\end{tabular}

income from livestock enterprises. Slightly more than one-fourth of all farms sold any crops cluring either year. The receipts from all crops sold, including truck and fruit, were less than half the value of feed bought during 1936. (Table 11.)

The average receipts per farm from crop sales during 1935 and 1936 were $\$ 58$ and $\$ 55$, respectively. Crop sales consisted largely of crops raised on land reasonably well protected from erosion. Most truck crops are grown on level or nearly level land, which is not subject to serious erosion.

It is not feasible that many of these farms can efficiently grow crops for sale. This is especially true of the non-erosion-resistant crops. It may be expected that crop sales will decrease rather than increase if erosion-resistant crops replace the soil-depleting grains now grown.

\section{LIVESTOCK}

Animal Units

Livestock, as has been pointed out, is the most important incomeproducing enterprise on the Jackson County farms. The number of animal units which available feed and pasture will maintain effi-

TABLE 12-Average number of animal units on 187 farms in Jackson area, $1935-36$

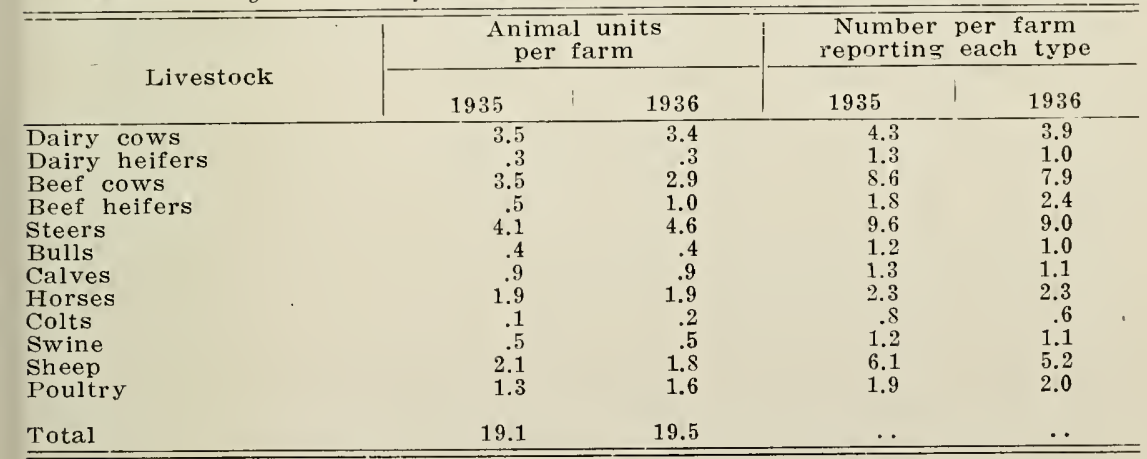


ciently is of great importance in determining the income to the farm operator. (Table 12.)

In 1935 there were about 19.1 animal units per farm, 13 of which were cattle. In the following year the average number of animal units maintained per farm was only a fraction higher. The slight increase was accounted for by increases in cattle and poultry.

The feed available per animal unit was much less per farm in 1936 than in 1935. In the case of roughage less than half as much was available as in 1935. Although grains were available in lesser quantities, the shortage in this respect was not as serious as was true of roughage. In subsequent years the feed available per animal unit may be profitably increased both in quantity and quality, and undoubtedly will be if legume hays find a general place in the arerage farm program. This should enable farmers to produce more livestock at a greater advantage.

\section{Livestock Inventory}

About $20 \%$ of the total investment in livestock was represented by work animals (Table 13). The value of beef aninials was abont $+1 \%$ of the total and the dairy stock value was about $23 \%$. The remaining $16 \%$ was divided between all other types of livestock. A1though about one-third of the farms reported an average flock of 50 sheep per farm, this type of livestock constituted little more than $6 \%$ of the total livestock investment per farm. Steers were reported on approximately half of all farms at the close of the second year's inventory. These data indicate that many farms were not stocked with the major income-producing enterprise of the area. A large percentage of the farms kept dual-purpose cattle along with some hogs and chickens for home consumption.

TABLE 13-Livestock inventory for 187 farms in Jackson area, 1935-36

\begin{tabular}{|c|c|c|c|c|}
\hline \multirow{2}{*}{ Livestock } & \multicolumn{2}{|c|}{$\begin{array}{c}\text { Value per farm } \\
\text { June } 1\end{array}$} & \multicolumn{2}{|c|}{$\begin{array}{l}\text { Percentage of } \\
\text { total value }\end{array}$} \\
\hline & 1935 & 1936 & 1935 & 1936 \\
\hline $\begin{array}{l}\text { Dairy cows and heifers } \\
\text { Beef cows and heifers } \\
\text { Steers }-1 \text { yr. } \\
\qquad 2 \text { yr. } \\
\text { Bulls and calves } \\
\text { Horses and colts } \\
\text { Swine } \\
\text { Sheen and lambs } \\
\text { Poultry }\end{array}$ & $\begin{array}{r}\$ 168.87 \\
173.11 \\
163.61 \\
\ldots \ldots \\
\cdots 3.50 \\
636.08 \\
32.09 \\
68.25 \\
70.94\end{array}$ & $\begin{array}{r}\$ 175.83 \\
184.02 \\
153.00 \\
79.41 \\
18.93 \\
75.77 \\
249.41 \\
32.92 \\
68.79 \\
86.43\end{array}$ & $\begin{array}{r}17.2 \\
17.6 \\
16.7 \\
\cdots \\
7.1 \\
24.0 \\
3.3 \\
6.9 \\
7.2\end{array}$ & $\begin{array}{r}15.6 \\
16.4 \\
13.6 \\
7.1 \\
1.7 \\
6.7 \\
22.2 \\
2.9 \\
6.1 \\
7.7\end{array}$ \\
\hline Total & $\$ 9 \$ 2.45$ & $\$ 1124.51$ & 100.0 & 100.0 \\
\hline
\end{tabular}

${ }^{1}$ Steers were not classified according to age in 1935.

\section{Livestock Purchases and Sales}

Steers constituted 40 to $54 \%$ of all livestock purchased during the tivo-year period (Table 14). The average total value of all live- 
stock purchased per farm was $\$ 200$ in 1935 and $\$ 163$ in 1936 . These values indicate a tendency toward a small cash "outlay" for productive livestock. There may be two reasons: (1) inability of the farmis to support additional stock on the available pasture and forage; and (2) lack of financial ability to purchase more. In either or both instances the income-earning capacity is necessarily affecterl because of the lack of basic livestock.

A large percentage of the livestock sold is raised on the respective farms. The average total receipts from livestock sales were $\$ 432$ in 1935 and $\$ 539$ in 1936. Steers constituted about $38 \%$ of the value of all sales in either year, while calves and lambs were next in importance. Although average sales per farm were small, chickens and calves were more generally sold by all farmers than any other class of livestock. It was the sale of steers, lambs, and other more valuable stock, although sold by fewer farmers, that materially increased the average farm income. However, it should not be construed that many farms could not increase net income by expanding the dairy and poultry interprises.

TABLE 14-Livestock purchases and sales on 187 farms in Jackson area, 1935-36

\begin{tabular}{|c|c|c|c|c|c|c|c|c|}
\hline \multirow[t]{2}{*}{ Livestock } & \multicolumn{2}{|c|}{$\begin{array}{l}\text { Value of } \\
\text { purchases } \\
\text { per farm }\end{array}$} & \multicolumn{2}{|c|}{$\begin{array}{l}\text { Percentage } \\
\text { of total } \\
\text { purchases }\end{array}$} & \multicolumn{2}{|c|}{$\begin{array}{l}\text { Value of } \\
\text { sales } \\
\text { perfarm }\end{array}$} & \multicolumn{2}{|c|}{$\begin{array}{l}\text { Percentage } \\
\text { of total } \\
\text { sales }\end{array}$} \\
\hline & 1935 & 1936 & 1935 & 1936 & 1935 & 1936 & 1935 & 1936 \\
\hline $\begin{array}{l}\text { Dairy cows } \\
\text { and heifers } \\
\text { Beef cows }\end{array}$ & $\$ 17.84$ & $\$ 17.70$ & S.9 & 10.9 & $\$ 32$ & $\$ 37$ & 7.4 & 6.9 \\
\hline and heifers & 11.16 & 15.94 & 5.6 & $9 . S$ & 36 & 57 & 8.4 & 10.6 \\
\hline Stcers & 105.20 & 65.63 & 54.0 & 40.4 & 165 & 203 & 38.3 & 37.6 \\
\hline Bulls & t.2s & 9.13 & 2.1 & 5.6 & 17 & 17 & 4.0 & 3.1 \\
\hline Calves & 6.07 & 2.87 & 3.0 & 1.8 & 38 & 54 & 8.8 & 10.0 \\
\hline $\begin{array}{l}\text { Horses } \\
\text { and colts }\end{array}$ & 21.04 & & 15.5 & & 25 & & & \\
\hline Swine & $\begin{array}{r}31.04 \\
8.35\end{array}$ & 8.36 & $\begin{array}{r}15.0 \\
4.2\end{array}$ & $\begin{array}{r}19.3 \\
5.1\end{array}$ & $\begin{array}{l}35 \\
26\end{array}$ & $\begin{array}{l}35 \\
24\end{array}$ & $\begin{array}{l}5.1 \\
5.9\end{array}$ & $\begin{array}{l}6.5 \\
4.4\end{array}$ \\
\hline Sheep & 4.12 & 4.80 & 2.1 & 3.0 & 36 & 47 & 8.4 & S.S \\
\hline Poultry & 9.15 & 5.94 & 4.6 & 3.6 & 47 & 65 & 10.7 & 12.1 \\
\hline Total & $\$ 200.21$ & $\$ 162.57$ & 100.0 & 100.0 & $\$+32$ & $\$ 539$ & 100.0 & 100.0 \\
\hline
\end{tabular}

\section{LIVESTOCK PRODUCTS}

Farmers sold eggs more than any other single livestock product. Practically all farm families kept a small flock of poultry from which they sold the eggs produced in excess of home consumption. This item constituted $46 \%$ of all inconle from livestock products in 1935 and $40 \%$ for the year following. (Table 15.)

Although sold by a very small percentage of farmers, fluid milk accounted for about $36 \%$ of all receipts from livestock products during either year. Cream was the dairy product most generally sold, but it was sold in relatively small quantities from the many general farms. A few farmers sold some butter. Wool was an important source of income to about $30 \%$ of the farms. This item did not contribute a major portion of gross farm receipts, but it did represent 
TABLE 15-Livcstock products sold from 187 farms in Jaclison area, 1935-36

\begin{tabular}{|c|c|c|c|c|c|c|c|c|c|}
\hline \multirow{2}{*}{\multicolumn{2}{|c|}{ Product }} & \multicolumn{2}{|c|}{$\begin{array}{c}\text { Price } \\
\text { per unit }\end{array}$} & \multicolumn{2}{|c|}{$\begin{array}{c}\text { Value } \\
\text { perfarm }\end{array}$} & \multicolumn{2}{|c|}{$\begin{array}{c}\text { Percentage } \\
\text { of total }\end{array}$} & \multicolumn{2}{|c|}{$\begin{array}{l}\text { Number } \\
\text { reporting }\end{array}$} \\
\hline & & 1935 & 1936 & 1935 & 1936 & 1935 & 1936 & 1935 & 1936 \\
\hline Milk & (gal.) & $\$ .26$ & $\$ .25$ & $\$ 90.67$ & $\$ 109.70$ & 36.4 & 36.1 & $s$ & 6 \\
\hline Cream & (lb.) & .21 & .30 & 27.05 & 34.92 & 10.9 & 11.5 & $4 S$ & 71 \\
\hline Butter & (11).) & .25 & .24 & 1.67 & 1.51 & .6 & .5 & 5 & 13 \\
\hline Wool & (11).) & .32 & .38 & 14.25 & 18.95 & 5.8 & 6.3 & 64 & 65 \\
\hline \multicolumn{10}{|l|}{ Market } \\
\hline Hatching & (1002.) & .19 & .21 & $11+.52$ & 122.23 & 46.0 & 40.3 & 165 & 162 \\
\hline eggs & (doz.) & $\cdots$ & .31 & $\therefore{ }^{1}$ & 11.22 & & 3.7 & & 20 \\
\hline \multirow{3}{*}{\multicolumn{2}{|c|}{$\begin{array}{l}\text { Honey } \\
\text { Breeding fees } \\
\text { Other }\end{array}$}} & $\cdots$ & . & .56 & 1.17 & .2 & .3 & 3 & 6 \\
\hline & & $\cdots$ & $\cdots$ & $\ddot{i}$ & 3.10 & . & 1.1 & 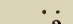 & 20 \\
\hline & & $\cdots$ & . & .11 & .57 & .1 & .2 & 3 & 20 \\
\hline \multicolumn{2}{|l|}{ Total } & & & $\$ 24$ S.\$3 & $\$ 303.37$ & 100.0 & 100.0 & 175 & 177 \\
\hline
\end{tabular}

IIncluded in market eggs.

an income item which was produced at a small cash cost. The average farm received $\$ 249$ for livestock products in 1935 and $\$ 303$ in 1936, or an increase of $22 \%$. Higher prices per unit were largely responsible for the increase.

\section{MISCELLANEOUS FARM INCOME}

Receipts other than from crop and livestock enterprises were relatively unimportant on most farms. Some farms pastured stock for neighbors, and a few sold some forest products.

Miscellaneous receipts amounted to $\$ 27$ per farm in 1936 , com pared with $\$ 7$ for the prior year. The increase was attributed largely to the payments of the Agricultural Adjustment Administration and to the increase of receipts from forest products, as indicated in? Table 16.

\section{NON-AGRICULTURAL INCOME}

Income from non-farm sources was excluded from farm incoms but was included in operator's earnings. During 1935 the average farm received $\$ 132$ from non-agricultural sources and $\$ 199$ during the

TABLE 16-Miscellaneous farm receipts on 187 farms in. Jackson area, 1935-36

\begin{tabular}{|c|c|c|c|c|c|c|}
\hline \multirow[t]{2}{*}{ Source } & \multicolumn{2}{|c|}{$\begin{array}{l}\text { Amount } \\
\text { per farm }\end{array}$} & \multicolumn{2}{|c|}{$\begin{array}{l}\text { Percentage } \\
\text { of total }\end{array}$} & \multicolumn{2}{|c|}{$\begin{array}{l}\text { Number } \\
\text { reporting }\end{array}$} \\
\hline & 1935 & 1936 & 1935 & 1936 & 1935 & 1936 \\
\hline $\begin{array}{l}\text { Stock pastured } \\
\text { Rent fronl land and }\end{array}$ & $\$ 3.11$ & $\$ 2.51$ & 43.9 & 9.3 & 17 & 23 \\
\hline buildings & .89 & .15 & 12.5 & .6 & 3 & 2 \\
\hline Team and machine work & .93 & 2.43 & 13.1 & 9.0 & 10 & 17 \\
\hline Operator's work & 1.06 & 1.10 & 15.0 & 4.1 & 10 & 7 \\
\hline Forest products & 1.10 & 3.03 & 15.5 & 34.0 & 3 & 11 \\
\hline A. A. A. ${ }^{1}$ & $\ldots$ & 6.95 & . & 25.9 & $\ldots$ & 40 \\
\hline Miscellaneous & $\cdots$ & 4.57 & $\therefore$ & 17.1 & . & 17 \\
\hline Total & $\$ 7.09$ & $\$ 26.80$ & 100.0 & 100.0 & 36 & 89 \\
\hline
\end{tabular}

${ }^{1}$ Payments for production control or other governmental programs were not recorded in 1935. 


\begin{tabular}{|c|c|c|c|c|c|c|}
\hline \multirow{2}{*}{ Source } & \multicolumn{2}{|c|}{$\begin{array}{c}\text { Amount } \\
\text { per fatrm }\end{array}$} & \multicolumn{2}{|c|}{$\begin{array}{c}\text { Percentage } \\
\text { of total }\end{array}$} & \multicolumn{2}{|c|}{$\begin{array}{l}\text { Number } \\
\text { reporting }\end{array}$} \\
\hline & 1935 & 1936 & 1935 & 1936 & 1935 & 1936 \\
\hline $\begin{array}{l}\text { Rent from land and } \\
\text { buildings } \\
\text { Trucking } \\
\text { Team and machine work } \\
\text { Operator's work } \\
\text { Royalties, leases } \\
\text { Miscellaneous }\end{array}$ & $\begin{array}{r}1.22 \\
20.85 \\
3.80 \\
76.94 \\
23.24 \\
6.28\end{array}$ & $\begin{array}{r}5.06 \\
7.49 \\
2.99 \\
112.23 \\
67.72 \\
3.56\end{array}$ & $\begin{array}{r}.9 \\
15.8 \\
2.8 \\
58.2 \\
17.6 \\
4.7\end{array}$ & $\begin{array}{r}2.6 \\
3.8 \\
1.5 \\
56.3 \\
34.1 \\
1.7\end{array}$ & $\begin{array}{r}2 \\
3 \\
5 \\
33 \\
16 \\
6\end{array}$ & $\begin{array}{r}8 \\
5 \\
12 \\
53 \\
102 \\
2\end{array}$ \\
\hline Total & $\$ 132.33$ & $\$ 199.05$ & 100.0 & 100.0 & 62 & 132 \\
\hline
\end{tabular}

following year. The major portion of these respective sums was derived from gas royalties and leases and from operator's work not related to farm operations. Recent developments of natural gas in the area undoubtedly will continue to give these farmers appreciable supplementary income. This industry also gives some work to farmers in the area. (Table 17.)

\section{TOTAL FARM RECEIPTS}

The total agricultural receipts averaged $\$ 747$ per farm in 1935 , and $\$ 924$ in 1936, an increase of $24 \%$ for the latter year. Crop receipts showed a small decline while the livestock enterprises showed larger returns in 1936, as indicated by data presented in Table 18 and in Figure 7.

The proportion of gross farm receipts derived from the various sources varied only slightly for the two years. Livestock, sold as meat or breeding stock, contributed approximately $58 \%$ of all agricultural receipts, while $33 \%$ of all receipts was derived from live-

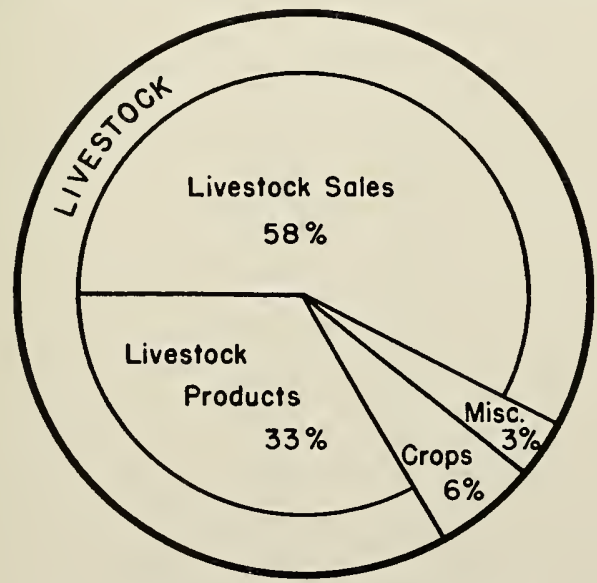

Fig. 7-Sources of cash farm income in Jackson County area, 1936 
TABLE 1S-Recapitulation of cash farm receipts of 187 farms in Jackson area, $1935-36$

\begin{tabular}{|c|c|c|c|c|}
\hline \multirow{2}{*}{ Receipts } & \multicolumn{2}{|c|}{ Amount per farm } & \multicolumn{2}{|c|}{ Percentage of total } \\
\hline & 1935 & 1936 & 1935 & 1936 \\
\hline Crops & $\$ 59$ & $\$ 55$ & 7.8 & 5.9 \\
\hline Livestock & 432 & 539 & 57.9 & $5 \$ .3$ \\
\hline Livestock products & 249 & 303 & 33.3 & 32.8 \\
\hline Miscellaneous receipts & 7 & 27 & 1.0 & 3.0 \\
\hline Total cash receipts & $\$ 747$ & $\$ 924$ & 100.0 & 100.0 \\
\hline
\end{tabular}

stock products. The remaining $9 \%$ was from crops and miscellaneous sources.

\section{FARM EXPENSES}

Current operating expenses, excluding labor, amounted to $\$ 251$ per farm in 1935 and $\$ 307$ per farm in 1936. Feeds, both concentrates and roughages, represented $36 \%$ and $46 \%$, respectively, of the total for the two years. These were largely mixed concentrate feeds.

Taxes were the next major item of farm expense, requiring about $\$ 30$ per farm or about $12 \%$ of all expenses in 1935 , while the cost of seeds exceeded taxes in 1936. It is surprising that production expenses such as seed, fertilizer, and lime were not higher in this area. However, high transportation costs tend to discourage the use of both fertilizer and lime, and the cost of legume seed generally was excessive during 1936. The proportion of the other items of expense varies somewhat from year to vear, but their relatively small values do not change the general picture markedly. (Table 19.)

The expenditures for labor, aside from operator's labor, nearly

TABLE 19-Current operating expenses ${ }^{1}$ of 187 farms in Jackson area, 1935-36

\begin{tabular}{|c|c|c|c|c|c|c|}
\hline \multirow{2}{*}{ Item of expense } & \multicolumn{2}{|c|}{$\begin{array}{l}\text { Average } \\
\text { per farm }\end{array}$} & \multicolumn{2}{|c|}{$\begin{array}{c}\text { Percentage } \\
\text { of total }\end{array}$} & \multicolumn{2}{|c|}{$\begin{array}{l}\text { Farms } \\
\text { reporting }\end{array}$} \\
\hline & 1935 & 1936 & 1935 & 1936 & 1935 & 1936 \\
\hline Roughag'e & $\$ \quad 8.81$ & $\$ 38.70$ & 3.5 & 12.6 & 42 & 92 \\
\hline Concentrates & 81.47 & 101.39 & 32.4 & 33.0 & 177 & 162 \\
\hline Feed preparation & 2.43 & 4.19 & 1.0 & 1.4 & 20 & 35 \\
\hline Fertilizer & 13.39 & 14.21 & 5.3 & 4.6 & 84 & 104 \\
\hline Lime & 3.94 & 11.05 & 1.6 & 3.6 & 14 & 37 \\
\hline Seeds and plants & 21.51 & 29.14 & 8.6 & 9.5 & 117 & 140 \\
\hline Marketing expense & 17.20 & 15.37 & 6.9 & 5.0 & 40 & $5 \mathrm{~s}$ \\
\hline Machine hire & 4.20 & 5.63 & 1.7 & 1.8 & 60 & 61 \\
\hline Professional service & 5.14 & 6.02 & 2.0 & 1.9 & 64 & 77 \\
\hline Taxes & 30.68 & 28.14 & 12.2 & 9.2 & 173 & 172 \\
\hline Insurance and licenses & 5.55 & 16.84 & 2.2 & 5.5 & 67 & 92 \\
\hline Interest charges & .79 & 1.56 & .3 & .5 & 7 & 15 \\
\hline Fuel and utilities & 11.15 & 8.89 & 4.4 & 2.9 & 103 & 114 \\
\hline Rent for land & $2.3 \mathrm{~s}$ & 4.10 & 1.0 & 1.3 & 10 & 15 \\
\hline Repairs & 27.17 & 9.43 & 10.8 & 3.1 & 146 & $118=$ \\
\hline Supplies & 8.05 & 5.32 & 3.2 & 1.7 & 39 & 49 \\
\hline Miscellaneous & 7.37 & 7.35 & 2.9 & 2.4 & 113 & 119 \\
\hline Total & $\$ 251.23$ & $\$ 307.33$ & 100.0 & 100.0 & 187 & 187 \\
\hline
\end{tabular}

${ }^{1}$ Excluding labor. 
TABle 20-Labor expense on 187 farms in Jackson arca, 1935-36

\begin{tabular}{|c|c|c|c|c|c|c|}
\hline \multirow{2}{*}{ Item } & \multicolumn{2}{|c|}{$\begin{array}{l}\text { Amount } \\
\text { per farm }\end{array}$} & \multicolumn{2}{|c|}{$\begin{array}{c}\text { Percentage } \\
\text { of total }\end{array}$} & \multicolumn{2}{|c|}{$\begin{array}{l}\text { Number } \\
\text { reporting }\end{array}$} \\
\hline & 1935 & 1936 & 1935 & 1936 & 1935 & 1936 \\
\hline $\begin{array}{l}\text { Wages } \\
\text { Board } \\
\text { Family labor }\end{array}$ & $\begin{array}{r}\$ 2.33 \\
16.97 \\
125.67\end{array}$ & $\begin{array}{r}\$ 84.02 \\
19.26 \\
140.35\end{array}$ & $\begin{array}{r}33.7 \\
7.8 \\
58.5\end{array}$ & $\begin{array}{r}34.4 \\
7.9 \\
57.7\end{array}$ & $\begin{array}{r}122 \\
86 \\
113\end{array}$ & $\begin{array}{r}135 \\
91 \\
121\end{array}$ \\
\hline Total & $\$ 214.97$ & $\$ 243.63$ & 100.0 & 100.0 & 164 & 172 \\
\hline
\end{tabular}

equaled all other expenses. The data in Table 20 indicate that the value of labor per farm was $\$ 215$ and $\$ 244$ in the respective years. About one-third of these amounts was paid out as cash wages, while $8 \%$ was board furnished to hired hands. The remaining $58 \%$ represents the estimated value of family labor.

The total of all current expenses per farm amounted to $\$ 466$ in 1935 and $\$ 551$ for the following year. The latter figure represents an increase over the former year of $18 \%$ as against an increase in cash receipts of $24 \%$. Evidently the increase in production expenses was accompanied by a somewhat greater increase in the value of the production.

\section{FARM BUSINESS SUMMARY}

The cash income of $\$ 746$ per farm in 1935 , and $\$ 924$ in 1936 , was accompanied by a gross increase of $\$ 203$ and $\$ 214$, respectively, in working capital. This increase in value of capital was largely appreciation in the value of livestock.

Current expenses were accompanied by outlay for livestock purchased, inventory decrease, and depreciation on improvements, equipment, and machinery in the proportions indicated in Table 21. Total expenses for 1935 amounted to $\$ \$ 09$ per farm against gross receipts of $\$ 949$. In 1936 total expenses amounted to $\$ 888$ out of $\$ 1138$ of total receipts per farm. This farm income amounted to $\$ 140$ per farm in the former year and $\$ 250$ in the latter, or an increase of $78 \%$. In terms of cash transactions, excluding inventory changes, unpaid labor charges, and annual depreciation, total cash farm income amounted to $\$ 223$ and $\$ 371$ per farm in the respective years. The latter value represents a 66\% increase over the cash income for 1935.

After deducting from farm income $5 \%$ interest on investment, an average labor income of minus $\$ 204$ and minus $\$ 102$ remains for the respective years. In other words, there was $2 \%$ earned on capital invested during the year 1935, and $3.6 \%$ earned on investment in 1936, allowing no return for operator's labor and management. Another standard of comparison may be had by eliminating from 'operator's labor income the charge for unpaid family labor. In this manner the value of family farm labor income may be derived. The value of unpaid family labor was $\$ 126$ and $\$ 140$ for the two years, 
TABLE 21-Financial summary of farm business on 187 farms in Jackson area, $1935-36$

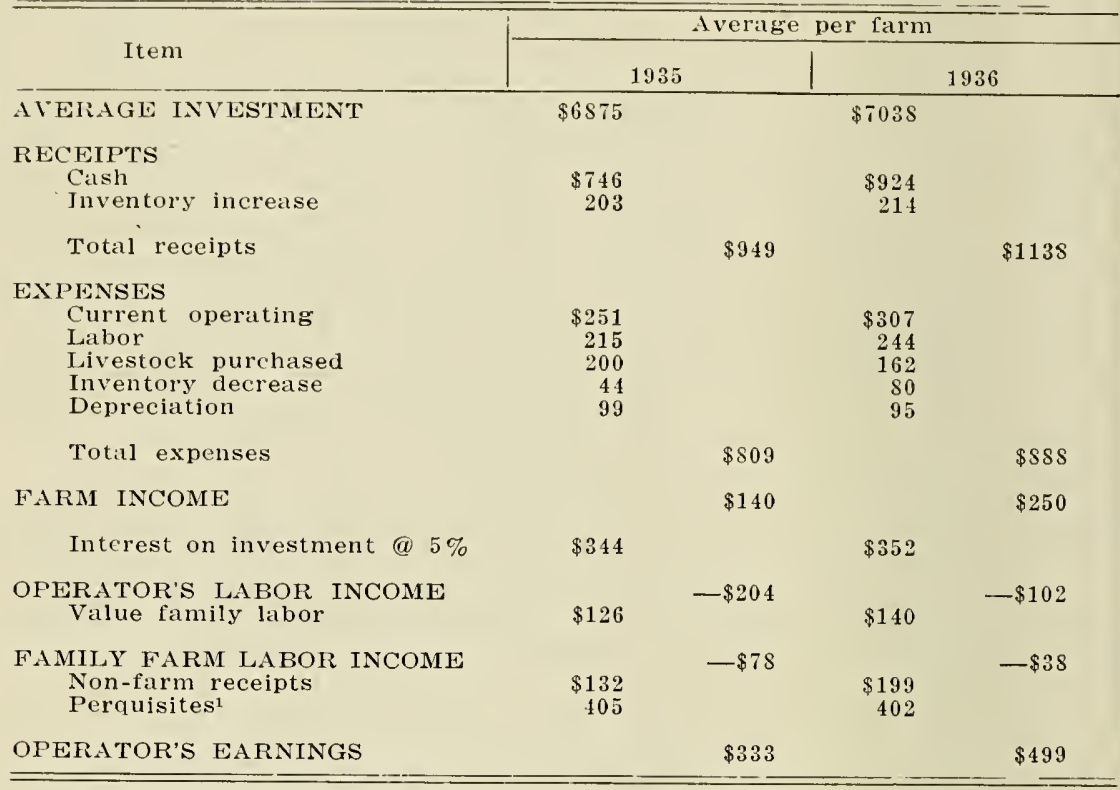

IIn addition to $\$ 298$ as value of food fumished family by farm for either year, house rent was credited at the rate of $10 \%$ of the value of dwelling.

respectively. When these values are added to operator's labor income there remains a family farm labor income of minus $\$ 78$ for 1935 and minus $\$ 38$ for 1936.

In addition to the income as a result of agricultural pursuits, the average family in the Jackson area received income from non-agricultural sources to the extent of $\$ 132$ and $\$ 199$ for the two respective years. As a complement to its livelihood the average family also received perquisites in the form of house rent and farm products consumed by the farm fanily, valued at $\$ 405$ per farm in 1935 , and $\$ 402$ in 1936. When these values were added to labor income there accrued an average operator's earning of $\$ 333$ and $\$ 499$ in 1935 and 1936 , respectively.

\section{Types of Farming ${ }^{6}$}

In the preceding section of this study data have beeil presented for the same farms for the years 1935 and 1936 . The objective has been to establish a basis for determining future trends in land use and agricultural production. In this section the factors that contributed to a more or less successful type of agricultural production on these

6 Detailed statistical summary for all farms, by types, may be found in the Appendix. 
farms will be pointed out. With these facts in mind it sliould be possible to evaluate the recommended program of soil and water conservation according to the manner and extent that it may affect the important factors of production. The implications of a program of this kind, in relation to production, will determine the feasibility of the program and the success that may be expected. For this purpesc, the data for 1936 will be used.

The different types of farms in West Virginia account for much of the wide variation between farms in respect to their busmess organization and income. The type of production is deternined largely by factors at least partially beyond the control of the former. Soil, topograply, climate, location, size of farm, and the farmer's own preference are factors which influence the prevailing types of production. In nany instances physical limitations do not permit the most profitable type of farm that might be desired by the farmer.

The most common type of farm in the Jackson area is the general farm, $49 \%$ of all farms being of this type. Few farms depended entirely on a single enterprise. General farms also contained about half the land in farms, with an average size of 178 acres. Self-sufficing farms were second in number but were third in amount of land included. Beef farms represented $33 \%$ of all land, while self-sufficing farms represented only $8 \%$ (Table 22). Poultry, dairy, and part-time farms were few in number but are important because of the different types of production which they represent. Poultry and dairy are nore specialized farms, while part-time farms constitute homesteads rather than a definite type of agricultural production.

TABLE 22-Types of farming on 187 farms in the Jackson area, 1936

\begin{tabular}{l|c|c|c|c|c}
\hline Type of farm & $\begin{array}{c}\text { Number } \\
\text { of farms }\end{array}$ & $\begin{array}{c}\text { Percentage } \\
\text { of farms }\end{array}$ & $\begin{array}{c}\text { Acres } \\
\text { in farms }\end{array}$ & $\begin{array}{c}\text { Percentage } \\
\text { of land } \\
\text { in farms }\end{array}$ & $\begin{array}{c}\text { Average } \\
\text { investment }\end{array}$ \\
\hline General & 91 & 49 & 178 & 48 & $\$ 7,223$ \\
Beef & 31 & 16 & 357 & 32 & 13,098 \\
Self-sufficing & 37 & 20 & 70 & 8 & 4,937 \\
Poultry & 11 & 6 & 181 & 4 & 10,750 \\
Dairy & 7 & 4 & 204 & 2 & 3,586 \\
Part-time & 10 & 5 & 80 & \\
\hline \hline
\end{tabular}

The average investment ranged from $\$ 13,098$ for beef farms to $\$ 1,937$ for self-sufficing farms. The size of farms, which ranged according to type from 357 acres to 70 acres, was responsible for much of the difference in size of investment. However, the value of land ranged from $\$ 37$ per acre for dairy farms to $\$ 15$ per acre for selfsufficing farms. Likewise the value of buildings and amount of working capital varied widely. The self-sufficing farms and many smaller general farms represent very small business units. This condition together with the low quality of land and the lack of other resources constitutes obvions limitations to profitable production for many farms.

The amount, quality, and slope of the land available deternine 


\begin{tabular}{l|c|c|c|c|c}
\hline \multirow{2}{*}{ Type } & \multicolumn{5}{c}{ Latud-use-Acres } \\
\cline { 2 - 5 } & Crops & Pasture & woodland & Other & Total \\
\hline General & 39 & 105 & 31 & 3 & 178 \\
Beef & 52 & 237 & 62 & 6 & 357 \\
Self-sufficing & 16 & 40 & 12 & 2 & 70 \\
Foultry & 41 & 100 & 37 & 3 & 181 \\
Thiry & 40 & 139 & 20 & 5 & 204 \\
Part-time & 12 & 48 & 18 & 2 & 80 \\
\hline
\end{tabular}

to a large extent the type of agricultural production that is possible. Hence large farms with extensive pasture areas were generally beefproducing farms. Farms of a medium size conveniently located and possessing comparatively high productive capacity were generally dairy farms. General farms and poultry farms were very similar, both in land-tuse and production patterns. except that poultry farmis specialized in that particular enterprise. In most cases the self. sufficing farms did not have much land available for either crops or pasture. Although probably originally low in value, destructive methods, combined with practically no effort to conserve the soil, continued to keep land values low. (Table 23.)

Like size of farm, cash farm receipts varied widely in amount. Dairy farms reported total cash farm receipts of $\$ 3581$, compared with $\$ 174$ for self-sufficing farms. Beef, poultry, and general farms ranked between the two extremes, in the order named. The sources of farm receipts did not vary greatly between the different types of farms. More than $90 \%$ of the receipts from all except gencral and selfsufficing farms was derived from livestock and livestock products. In the case of general farms, there were a few instances where truck and small fruits were sold, which accounted for a larger proportion of crop receipts. The limiting factor in farm production appeared to

TABLE 24-Source of receipts and income by type of farms, 1936

\begin{tabular}{|c|c|c|c|c|c|c|}
\hline & \multicolumn{6}{|c|}{ Type of Farm } \\
\hline & General & Beef & $\begin{array}{c}\text { Self- } \\
\text { sufficing }\end{array}$ & Poultry & Dairy & $\begin{array}{c}\text { Part-time } \\
\text { (abnorma1) }\end{array}$ \\
\hline Total cash farm receipts & $\$ 79 S$ & $\$ 1835$ & $\$ 174$ & $\$ \$ 97$ & $\$ 35 \$ 1$ & $\$ 193$ \\
\hline $\begin{array}{l}\text { Percent of total } \\
\text { Crops } \\
\text { Livestock } \\
\text { Livestock products } \\
\text { Miscellineous }\end{array}$ & $\begin{array}{l}10.7 \\
53.7 \\
30.7 \\
4.9\end{array}$ & $\begin{array}{r}3.4 \\
87.3 \\
8.3 \\
1.0\end{array}$ & $\begin{array}{r}3.1 \\
52.6 \\
35.7 \\
8.6\end{array}$ & $\begin{array}{r}.4 \\
42.4 \\
55.9 \\
1.3\end{array}$ & $\begin{array}{r}1.0 \\
12.8 \\
85.4 \\
.8\end{array}$ & $\begin{array}{r}3.7 \\
64.5 \\
26.7 \\
5.1\end{array}$ \\
\hline Farm income & $\$ 231$ & $\$ 560$ & $-\$ 36$ & $\$ 187$ & $\$ 150 \mathrm{~s}$ & $-\$ 299$ \\
\hline $\begin{array}{l}\text { Labor income } \\
\text { Perquisites }{ }^{1} \\
\text { Non-farm receipts }\end{array}$ & $\begin{array}{r}-\$ 137 \\
444 \\
175\end{array}$ & $\begin{array}{r}\$ 99 \\
427 \\
275\end{array}$ & $\begin{array}{r}\$ 133 \\
271 \\
66\end{array}$ & $\begin{array}{r}\$ 53 \\
427 \\
155\end{array}$ & $\begin{array}{r}\$ 958 \\
425 \\
180\end{array}$ & $\begin{array}{r}\$ 477 \\
385 \\
739\end{array}$ \\
\hline Operator's earnings & $\$ 482$ & $\$ 603$ & $\$ 204$ & $\$ 529$ & $\$ 1563$ & $\$ 647$ \\
\hline
\end{tabular}

${ }^{I}$ Includes value of food obtained from farm and house rent at rate of $10 \%$ of value of dwelling. 
be the anount or volume of business rather than the kind of commodities produced.

Dairy farms produced the lighest farm incomes, or an average of $\$ 1508$ per farm. Part-time and self-sufficing farms were the lowest, with minus $\$ 299$ and mint:s $\$ 36$, respectively. lieef, general, and poultry farms reported average farm incomes of $\$ 560, \$ 231$, and $\$ 187$, respectively. (Table 24 and Fig. 8.)

Dairy farms were the only type that earned an interest of $5 \%$ on investment, in excess of all production costs other than interest. All other types of farms, on the average, received minis labor incomes, ranging in anounts from minus $\$ 53$ on poultry farms to minus $\$ 477$ on part-time farms. There were, however, individual farms of each type which earned positive incomes.

In addition to labor income, the farm families received from the farm food and shelter valued at $\$ 4+4$ on general farms and $\$ 271$ on selisufficing farms. As non-farm income, the beef farm operators received $\$ 275$ and the self-sufficing operators received $\$ 66$. These items, together with labor income, constitute operator's earnings in the amount of $\$ 1563$ for dairy farms, ranging down to $\$ 204$ for selfsufficing farms.

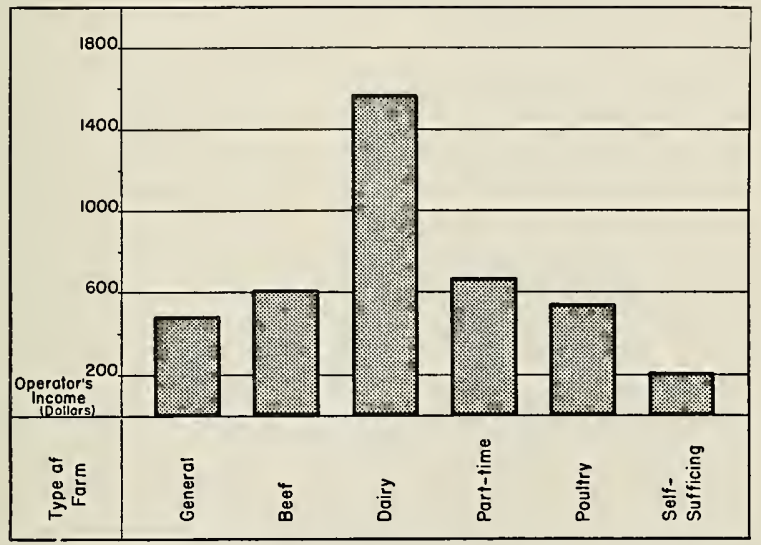

Fig. 8-Average operator's earnings by type of farm

\section{GENERAL FARMS}

Farms were classified as "general" if the value of products from any one source did not represent as much as $40 \%$ or more of the total value of all farm production and if they were not self-sufficing or part-time. ${ }^{\top}$ Forty-nine percent of all farms were classified as general in the Jackson area for 1936 . They represent about $48 \%$ of all land included in the survey. For purposes of analysis the 91 general farms were divided into three groups according to value of labor in-

iRefer to sections on self-sufficing and part-time farming for definitions of these types. 
come earned. Data concerning the organization, physical characteristics, and inconne will be presented in an effort to point out the salient factors which affect profitable agricultural production.

\section{Size of Business}

Size of business determines the potential productive capacity on onc hand and the actual current production on the other. The amount of physical investment may be sufficient, but if the volume of production is not of equally large proportions the large investment may prove to be a liability rather than an asset. This principle is plainly illustrated by data in Table 25.

The farms having highest labor incomes represented an investment about three-fourths as large as those farms having the lowest inconnes, and they were abont 20 acres smaller. On the other liand, the number of animal units maintained was the same, but the gross receipts were $28 \%$ higher, while expenses were $33 \%$ lower for those with highest labor incomes. This illustrates the advantage of using the investment to the fullest extent. A large investment producing less than its capacity is less productive than a smaller investment used more efficiently. There evidently was a clefinite lack of management on the larger farms with lowest labor incomes.

Contrasted with the farms having highest and lowest labor incomes, Table 25 shows an intermediate group which did not appear to possess the necessary scope, or size, of physical plant. The value of investment was low and the area in farms was not large enough to accommodate a business of sufficient volume for a high income. Normally, these farms would probably have been classed as having the lowest labor income, if the largest farms had produced in accordance with the size of their investment. The farms of small areas supporting fewer animal units, failed to produce sufficient gross income to justify the expenses incurred. It may be noted that the gross exTABLE 25-Relation of size of business to relative profitableness on general farms, 1936

\begin{tabular}{l|c|c|c}
\hline \hline Measure of size & $\begin{array}{c}\text { Average for 30 } \\
\text { highest labor } \\
\text { incomes }\end{array}$ & $\begin{array}{c}\text { Average for 30 } \\
\text { medium labor } \\
\text { incomes }\end{array}$ & $\begin{array}{c}\text { Average for } 31 \\
\text { lowest labor } \\
\text { incomes }\end{array}$ \\
\hline Average investment & $\$ 6988$ & $\$ 5281$ & $\$ 9329$ \\
Total farm acreage & 186 & 142 & 205 \\
Crop acreage & 40 & 33 & 44 \\
Pasture acreage & 112 & 75 & 5 \\
Number beef cattlet & 7 & 2 & 5 \\
Number steers & 24 & 16 & 24 \\
Total animal units & $\$ 1331$ & $\$ 770$ & $\$ 52$ \\
Total receipts & 688 & 640 & 1020 \\
Total expenses & 284 & -130 & -58 \\
Farm income & 51.6 & 83.1 & -546 \\
Labor income & & -136 & 107.1 \\
Ratio of expenses to receipts &
\end{tabular}

${ }^{1}$ Includes beef cows and heifers. 


\begin{tabular}{|c|c|c|c|c|c|c|c|c|c|c|}
\hline 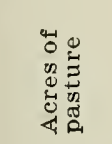 & 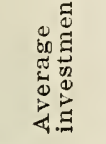 & 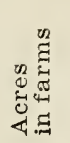 & 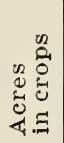 & 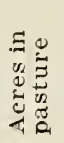 & 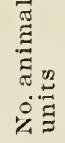 & 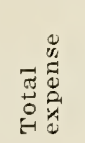 & 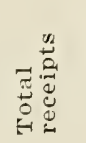 & $\underset{\Xi}{\Xi}$ & 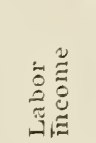 & 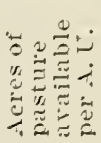 \\
\hline $\begin{array}{l}101-150 \\
151-\text { over }\end{array}$ & $\begin{array}{r}\$ 5,705 \\
4,950 \\
8,827 \\
11,503\end{array}$ & $\begin{array}{r}87 \\
134 \\
207 \\
297\end{array}$ & $\begin{array}{l}27 \\
36 \\
40 \\
52\end{array}$ & $\begin{array}{r}35 \\
71 \\
126 \\
198 \\
\end{array}$ & $\begin{array}{l}10 \\
16 \\
27 \\
32\end{array}$ & $\begin{array}{r}\$ 522 \\
664 \\
879 \\
1113\end{array}$ & $\begin{array}{r}\$ 660 \\
761 \\
1396 \\
1402\end{array}$ & $\begin{array}{r}\$ 138 \\
97 \\
517 \\
289 \\
\end{array}$ & $\begin{array}{r}\$ 148 \\
-151 \\
75 \\
-287 \\
\end{array}$ & $\begin{array}{r}7 \\
6 \\
6 \\
10 \\
\end{array}$ \\
\hline
\end{tabular}

penses of these small farms were practically as large as those of the most profitable farms.

The outstanding virtue of the farms with intermediate incomes, in comparison with the larger low-income farms, was their small investment. Size of farm and investment are very important considerations in farm management. The unit should be large enough to support sufficient production, but not so large that it cannot be stocked and managed efficiently. It is quite possible to obtain a farm that is too large for one man, possessing limited credit and financial ability, to manage properly.

Economy in the production of good livestock under West Virginia conditions depends greatly on the pasture available. Because of the generally poor quality of pastures in this area, a large acreage is necessary to support a large livestock enterprise. The data in Table 26 illustrate the importance of having enough pasture to support a sufficient number of animal units for yielding a reasonably iarge income.

However, these data also illustrate the ill effects on income of large acreages of pasture that are not utilized fully. The larger farms did not maintain enough livestock to use all available pasture as efficiently as did the farms of medium size. On the large farms the average pasture load was one animal wnit to 10 acres, while the more efficient farms of medium size maintained one animal unit to 6 acres of pasture. There were 72 acres more of pasture land available for only five more animal units on the least efficient larger farms than was true of the most efficient medium-sized farms. Possibly the pastures on the larger farms were not as productive as those of the farms of medium size. But this was not indicated by the corresponding crop index. The variation of the average crop-yield index for the farms in different groups was not wide enough to indicate significant differences in productivity, according to size of farms. Therefore it seems that volume of production, controlled largely by management, should correspond closely to the size of investment if profit is to be obtained.

The direct influence of volume of animal production is emphasized again in Table 27. Expenses do not increase directly as income increases coincident with an increase in the volume of production. 
'I'ABLE 27-Association of various factors with number of animal units maintained on general farms, 1936

\begin{tabular}{|c|c|c|c|c|c|c|c|c|c|c|}
\hline 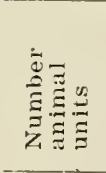 & 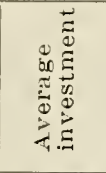 & 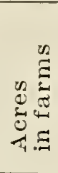 & 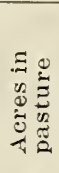 & 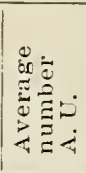 & 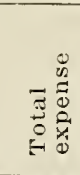 & 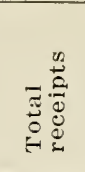 & छ & 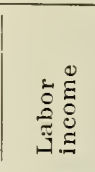 & 递 & 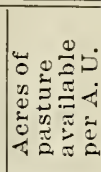 \\
\hline $\begin{array}{r}1-12 \\
13-24 \\
25-36 \\
37-0 v e r \\
\end{array}$ & $\begin{array}{r}\$ 4,745 \\
6,469 \\
9,798 \\
12,900 \\
\end{array}$ & $\begin{array}{l}101 \\
166 \\
238 \\
300 \\
\end{array}$ & $\begin{array}{r}54 \\
96 \\
144 \\
193 \\
\end{array}$ & $\begin{array}{r}9 \\
18 \\
29 \\
48\end{array}$ & $\begin{array}{r}\$ 563 \\
726 \\
1066 \\
1065\end{array}$ & $\begin{array}{r}\$ 533 \\
921 \\
1552 \\
1611\end{array}$ & $\begin{array}{r}-\$ 30 \\
195 \\
486 \\
545\end{array}$ & $\begin{array}{r}-\$ 267 \\
-128 \\
-100 \\
-14\end{array}$ & $\begin{array}{l}69 \\
67 \\
69 \\
68\end{array}$ & $\begin{array}{r}11 \\
6 \\
5 \\
4\end{array}$ \\
\hline
\end{tabular}

The farms maintaining the largest number of animal units that available pastures would support proved to be the most profitable. Pastures were utilized more fully and more income was produced. In contrast, by referring back to Table 26, the futility of large farnis and extensive pasture areas, without an efficient number of animal units, may be seen. Many major overhead expenses remain about constant regardless of the efficiency with which land is atilized. Each additional unit of production costs less, and the percentage profit is greater up to the optimum productive capacity.

It is clearly illustrated in Table 28 that the volume of business, in the form of livestock receipts, had a greater and more direct effect on labor income than any other factor. Managerial and efficiency factors affect the comparative profitableness of the business. Certainly, large farms and pastures of high quality are necessary for supplying sufficient grazing to a greater number of animal units. These are prerequisite factors, but the amount of products sold is the most important factor in producing income. Since $88 \%$ of all receipts was derived from livestock and livestock products, it is evident that this source of receipts should be given primary attention.

\section{Efficiency of Operation}

In order that the larger farms can produce the greatest volume of income in the most advantageous manner, certain efficiency factors must not be neglected. The most important of these is the efficiency in the use of pastures. As previously pointed out, large areas of pasture may be available but if they are not efficiently used in the production of high-quality livestock the return on the investment will be low (Table 29).

TABLE 28-Relative importance of volume of livestock receipts and associated factors to income on general farms, 1936

\begin{tabular}{|c|c|c|c|c|c|c|c|c|c|c|}
\hline 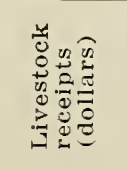 & 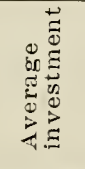 & 党: & 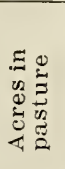 & 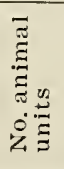 & 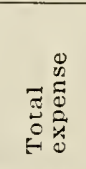 & 竞: & घ & 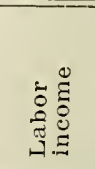 & 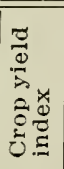 & 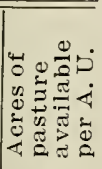 \\
\hline $\begin{array}{r}1-250 \\
251-500 \\
501-750 \\
751 \text {-over } \\
\end{array}$ & $\begin{array}{r}\$ 6055 \\
7386 \\
8827 \\
8255\end{array}$ & $\begin{array}{l}130 \\
176 \\
198 \\
268\end{array}$ & $\begin{array}{r}76 \\
98 \\
123 \\
175\end{array}$ & $\begin{array}{l}14 \\
21 \\
23 \\
36\end{array}$ & $\begin{array}{r}\$ 632 \\
754 \\
905 \\
1083\end{array}$ & $\begin{array}{r}\$ 695 \\
950 \\
1279 \\
1613\end{array}$ & $\begin{array}{r}\$ 63 \\
196 \\
374 \\
531\end{array}$ & $\begin{array}{r}-\$ 240 \\
-174 \\
-67 \\
118\end{array}$ & $\begin{array}{l}71 \\
65 \\
69 \\
66\end{array}$ & $\begin{array}{l}8 \\
6 \\
6 \\
6\end{array}$ \\
\hline
\end{tabular}


TABLE 29-Relation of efficiency in use of pastures and other factors to income on general farms, 1936

\begin{tabular}{|c|c|c|c|c|c|c|c|c|c|}
\hline 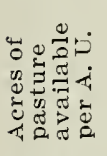 & 党 & 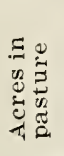 & 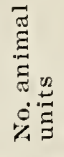 & 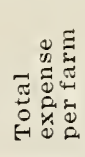 & 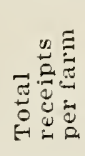 & 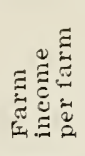 & 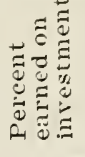 & 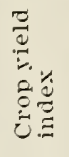 & 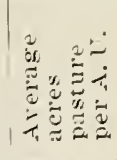 \\
\hline $\begin{array}{l}2-3.9 \\
4-5.9 \\
6-7.9 \\
8 \text {-over }\end{array}$ & $\begin{array}{l}151 \\
174 \\
177 \\
210\end{array}$ & $\begin{array}{r}66 \\
102 \\
115 \\
138\end{array}$ & $\begin{array}{l}24 \\
24 \\
20 \\
14\end{array}$ & $\begin{array}{l}\$ 775 \\
824 \\
841 \\
654\end{array}$ & $\begin{array}{r}\$ 1091 \\
1116 \\
995 \\
778\end{array}$ & $\begin{array}{r}\$ 316 \\
291 \\
154 \\
124\end{array}$ & $\begin{array}{l}4.2 \\
3.6 \\
2.0 \\
2.0\end{array}$ & $\begin{array}{l}63 \\
70 \\
66 \\
71 \\
\end{array}$ & $\begin{array}{r}3.3 \\
4.8 \\
6.7 \\
15.0\end{array}$ \\
\hline
\end{tabular}

A high rate of return on investment is shown to iepend directly on the full and efficient use of pasture. The farms maintaining iess than four acres of pasture per animal unit returned $4.2 \%$ on investments, while the farms maintaining eight or more acres of pasture per animal unit returned only $2.0 \%$ on investments. In other words, the farms which ntilized the fewest acres of pasture per animal unit returned the highest net incomes. Although there was no indication that fertility was any higher on the most efficient general farms, in!provement in the quality of pastures will undoubtedly aid more efficient production. Such improvement would provide greater efficiency in the use of land by making a greater return per acre.

In accordance with foregoing suggestions for an increase in the volume of production, it is shown that farm expenses did not vary in proportion to the variation in volume of receipts. It may be noted that the relative efficiency in the use of capital was responsible for a variation of more than $50 \%$ in the ratio of expenses to receipts. Many of the larger farms, necessitating relatively high overhead costs. were operated so inefficiently that volume of production was not sufficient to justify the high costs involved.

Only slight variations in prices received for farm products by the high- and the low-income groups were found. Nevertheless, it is well to keep in mind the fact that high-quality pastures and forage crops are necessary in producing livestock that will command "top" prices. Undoubtedly more attention to this factor would have a definite positive effect on labor income.

\section{Organization and Combination of Enterprises}

The organization of the enterprises on general farms was more or less similar regardless of size and efficiency of the unit. Major differences in income seemed to result from inadequate size and inefficient utilization rather than from kind or combination of enterprises. However, there was a tendency for the most profitable farms to possess an advantage in organization and operation. The data indicate that the most profitable farms had a greater proportion of their investment in productive livestock rather than in buildings and unused land. There was practically no difference in the value of land per acre between the highest and the lowest income groups. 
The farms having the highest incomes had slightly less land in low-producing grains and more in hay than did the low-income farms. Because of very low crop yields and the depletion of soil by grain crops, it is probably turclesirable to raise more grain than can be grown on arailable land of high-yielding ability. The most profitable farms gained a larger percentage of their gross income irom livestock and less from crop production. This fact suggests again that land, should be used for forage and pasture for the support of livestock. Crops for sale were losing enterprises because of their low productive advantage, compared with pasture and forage.

The least profitable farms expended twice as much for feed and labor as dicl the most profitable farms, while their gross receipts were $28 \%$ less. It is eviclent that the productive factors were poorly ntilized on the least profitable farms. A general tendency in the direction of more intensive livestock production, accompanied by more efficient utilization of land for forage and pasture production, appears to be the need on those farms not operating profitably. The amount and quality of pasture and hay available will determine the relative profitableness of livestock farming in this area. More efficient use of labor, and improvement of soil productivity, by producing crops of higher comparative advantage and types of livestock en-

TABLE 30-Organization of farm production according to income groups for 91 general farms, 1936

\begin{tabular}{|c|c|c|c|}
\hline Factor & $\begin{array}{c}\text { Average for } \\
30 \text { highest } \\
\text { income farms }\end{array}$ & $\begin{array}{c}\text { Average for } \\
30 \text { medium } \\
\text { income farms }\end{array}$ & $\begin{array}{c}\text { Average for } \\
31 \text { lowest } \\
\text { income farms } \\
\end{array}$ \\
\hline $\begin{array}{l}\text { Percentage of investment in: } \\
\text { Land } \\
\text { Dwelling } \\
\text { Farm buildings } \\
\text { Livestock } \\
\text { Other }\end{array}$ & $\begin{array}{r}49.5 \\
15.0 \\
12.1 \\
17.4 \\
6.0\end{array}$ & $\begin{array}{r}47.3 \\
16.6 \\
13.6 \\
16.2 \\
6.3\end{array}$ & $\begin{array}{r}51.5 \\
17.0 \\
12.3 \\
14.4 \\
4.8\end{array}$ \\
\hline $\begin{array}{l}\text { Value of land per acre } \\
\text { Crop acreage }\end{array}$ & $\begin{array}{r}\$ 23 \\
40\end{array}$ & $\begin{array}{r}\$ 22 \\
33\end{array}$ & $\begin{array}{r}\$ 24 \\
44\end{array}$ \\
\hline $\begin{array}{l}\text { Percentage of erop land in: } \\
\text { Corn } \\
\text { Wheat } \\
\text { Grain hay } \\
\text { Hay }\end{array}$ & $\begin{array}{r}20.0 \\
10.3 \\
2.6 \\
58.0\end{array}$ & $\begin{array}{r}22.2 \\
10.9 \\
3.1 \\
56.5\end{array}$ & $\begin{array}{r}19.3 \\
12.9 \\
2.9 \\
51.8\end{array}$ \\
\hline $\begin{array}{l}\text { Percentage of total receipts from: } \\
\text { All ljvestock } \\
\text { Cows and heifers } \\
\text { Steers } \\
\text { Calves } \\
\text { Lambs } \\
\text { Poultry } \\
\text { Livestock products } \\
\text { Crops }\end{array}$ & $\begin{array}{r}56.8 \\
9.1 \\
11.9 \\
4.3 \\
7.6 \\
8.1 \\
30.6 \\
8.7\end{array}$ & $\begin{array}{r}49.8 \\
9.4 \\
10.4 \\
6.0 \\
7.6 \\
7.7 \\
32.8 \\
9.7\end{array}$ & $\begin{array}{r}53.1 \\
10.1 \\
11.5 \\
4.5 \\
-4.5 \\
10.3 \\
29.1 \\
14.1\end{array}$ \\
\hline $\begin{array}{l}\text { Percentage of total expenses for: } \\
\text { Fertilizer and lime } \\
\text { Seed } \\
\text { Feed } \\
\text { Labor } \\
\text { Livestock purchased }\end{array}$ & $\begin{array}{r}5.1 \\
4.2 \\
11.1 \\
34.0 \\
24.3\end{array}$ & $\begin{array}{r}3.9 \\
4.6 \\
11.2 \\
34.9 \\
17.9\end{array}$ & $\begin{array}{r}3.3 \\
4.0 \\
13.5 \\
44.0 \\
13.0\end{array}$ \\
\hline
\end{tabular}


terprises in accorlance with the amount of land and other resources available, would undoubtedly increase the profitableness of the present less profitable farms. (Table 30.)

\section{SPECIALIZED BEEF.CATTLE FARMS}

Beef-cattle farms were those gaining $40 \%$ or more of their tolal income from this class of livestock. They were larger than farms of other types, consisting on the average of 357 acres. Thus a more extensive type of production, with respect to land use, is inherent. About $17 \%$ of all farms surveyed in the Jackson area were of this type, and they representer $33 \%$ of all land in the farms studied.

\section{Size of Business}

The data in Table 31 illustrate the importance of size of business. The farms with more acres and with more pasture scem to have produced a greater number of animal units from which practically $90 \%$ of all farm income was derived. It must be noted, however, that acres in farms and pasture are important only insofar as they are available in sufficient quantities for the profitable prosluction of beef animals. Hence, the amount of income produced depends on the 11umber of animal wnits that can be hand!ed economically. Sufficiently high yielding pastures are requisite to such production.

A direct comparison of the average cash receipts of the most profitable and least profitable farms follows:

\begin{tabular}{|c|c|c|c|c|}
\hline & \multicolumn{4}{|c|}{ Average value of sales } \\
\hline & Cows & Meifers & Calves & Sterers \\
\hline 15 most profitable farms & $\$ 156$ & $\$ 135$ & $\$ 230$ & $\$ 1161$ \\
\hline 16 least profitable farms & 122 & 75 & 106 & 742 \\
\hline
\end{tabular}

These four items constituted slightly less than $80 \%$ of all cash receipts. Hence the less profitable farms seem to have lacked the volume of business that was needed to produce a high labor income.

TABLE 31-Tiation of size of business to relative profitableness of beef farms, 1936

\begin{tabular}{|c|c|c|}
\hline Measure of size & $\begin{array}{c}\text { Average for } \\
15 \text { farms with } \\
\text { highest labor } \\
\text { incomes }\end{array}$ & $\begin{array}{c}\text { Average for } \\
16 \text { farms with } \\
\text { lowest labor } \\
\text { incomes }\end{array}$ \\
\hline Average investment & $\$ 14,572$ & $\$ 11, S S T$ \\
\hline $\begin{array}{l}\text { Total farm acreage } \\
\text { Crop acreage } \\
\text { Pasture acreage } \\
\text { Number beef cattle } \\
\text { Number steers } \\
\text { Total animal units }\end{array}$ & $\begin{array}{r}402 \\
57 \\
261 \\
41 \\
21 \\
53\end{array}$ & $\begin{array}{r}314 \\
47 \\
214 \\
25 \\
17 \\
35\end{array}$ \\
\hline $\begin{array}{l}\text { Total receipts } \\
\text { Total expenses } \\
\text { Farm income } \\
\text { Labor income }\end{array}$ & $\begin{array}{r}\$ 3,008 \\
1,804 \\
1,204 \\
475\end{array}$ & $\begin{array}{r}\$ 1,59 \mathrm{~S} \\
1,642 \\
-44 \\
-63 \mathrm{~S}\end{array}$ \\
\hline
\end{tabular}

${ }^{1}$ Includes beef cows, heifers, and steers. 
TABLE 32-Relation of number of animal units and associated factors to income on bcef farms, 1936

\begin{tabular}{|c|c|c|c|c|c|c|c|c|c|}
\hline 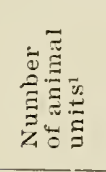 & 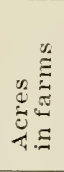 & 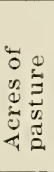 & 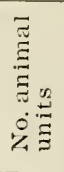 & 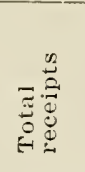 & 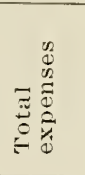 & 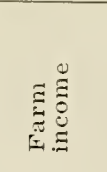 & $\begin{array}{l}\stackrel{0}{\Xi} \\
\stackrel{\Xi}{\Xi} \\
\stackrel{\Xi}{\Xi}\end{array}$ & 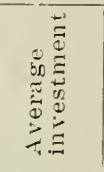 & 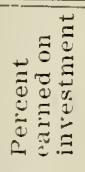 \\
\hline $\begin{array}{c}0-29.9 \\
30-59.9 \\
60-\text { over }\end{array}$ & $\begin{array}{l}195 \\
322 \\
674\end{array}$ & $\begin{array}{l}130 \\
224 \\
428\end{array}$ & $\begin{array}{l}20.9 \\
39.8 \\
77.2\end{array}$ & $\begin{array}{r}\$ 1024 \\
2469 \\
3905\end{array}$ & $\begin{array}{r}\$ 1080 \\
1651 \\
2856\end{array}$ & $\begin{array}{r}56 \\
818 \\
1049\end{array}$ & $\begin{array}{r}-\$ 418 \\
137 \\
-36\end{array}$ & $\begin{array}{r}\$ 7240 \\
13623 \\
21719\end{array}$ & $\begin{array}{r}-0.7 \\
6.0 \\
4.8\end{array}$ \\
\hline
\end{tabular}

${ }^{1}$ Animal units pastured.

It may be noted (Table 32) that high farm inconses were associated with larger units of production, but the proportionate increase in incone on the larger farms was not sufficient fully to justify the greater investment in the extremely large units. Higliest incomes seemed to be associated with business units of an intermediate size that can be financed and managed more efficiently. This fact is further emphasized in Table 33. The larger farms did not have gross receipts of sufficient volume to justify the additional expense that was involved in the larger investment. This leads to the suggestion that there was an appreciable degree of inefficiency associated with the operation of the larger farms although they were not completely wnprofitable.

\section{Efficiency of Operation}

Inefficiency in the production of pasture appears to account for low labor incomes to a greater degree than any other factor on beef farms, assuming that size of unit is large enough to be profitable. High-yielding pastures eliminate the necessity of a greater investment in a large area of low-yielding land.

It may be noted in Table 34 that, in general, farms having the largest pasture acreage per animal unit received the lowest labor in. comes. The deficiency might be attributed to understocking of the larger pastures. However, a low pasture load was invariably associated with low crop yields on these farms. This combination of facts seems to indicate that there is definite need for pasture improvement on some farms which would enable the efficient production of a larger number of income-producing livestock.

TABLE 33-Association of various factors with acreage of pasture on beef farms, 1936

\begin{tabular}{|c|c|c|c|c|c|c|c|c|c|}
\hline 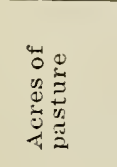 & 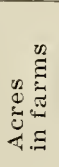 & 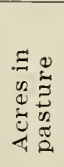 & 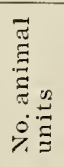 & 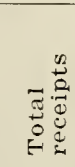 & 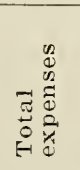 & 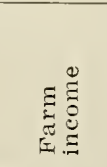 & 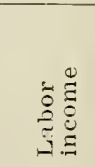 & 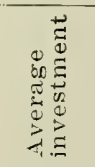 & 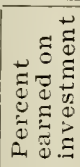 \\
\hline $\begin{array}{c}1-150 \\
151-300 \\
301 \text {-over }\end{array}$ & $\begin{array}{l}176 \\
308 \\
661\end{array}$ & $\begin{array}{l}103 \\
209 \\
4+9\end{array}$ & $\begin{array}{l}24.1 \\
41.8 \\
71.3\end{array}$ & $\begin{array}{r}\$ 910 \\
2908 \\
2973\end{array}$ & $\begin{array}{r}954 \\
1895 \\
2395\end{array}$ & $\begin{array}{r}\$ 4 \\
1013 \\
578\end{array}$ & $\begin{array}{r}\$ 374 \\
287 \\
385\end{array}$ & $\begin{array}{r}\$ 6594 \\
13482 \\
19262\end{array}$ & $\begin{array}{r}-0.6 \\
7.5 \\
3.0\end{array}$ \\
\hline
\end{tabular}


TABLE 34-Association of pasture acreage por animal unit and olher fuctors with income on beef farms, 19396

\begin{tabular}{|c|c|c|c|c|c|c|c|c|}
\hline 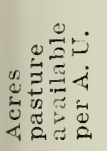 & 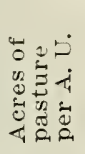 & 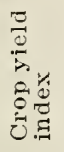 & 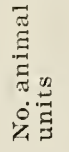 & 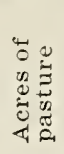 & 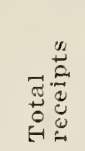 & ‡ & 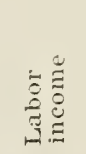 & 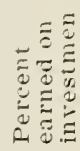 \\
\hline $\begin{array}{l}2-3.9 \\
4-5.9 \\
6-7.9 \\
\text { 8-over }\end{array}$ & $\begin{array}{r}3.3 \\
5.0 \\
6.5 \\
11.4\end{array}$ & $\begin{array}{l}79.8 \\
69.7 \\
63.5 \\
63.3\end{array}$ & $\begin{array}{l}49.8 \\
43.1 \\
50.6 \\
29.2\end{array}$ & $\begin{array}{l}167 \\
201 \\
311 \\
331\end{array}$ & $\begin{array}{r}\$ 3333 \\
1879 \\
2359 \\
2047\end{array}$ & $\begin{array}{r}\$ 1014 \\
396 \\
673 \\
340\end{array}$ & $\begin{array}{r}\$ 214 \\
-172 \\
-118 \\
-249\end{array}$ & $\begin{array}{l}6.3 \\
3.5 \\
4.3 \\
2.8\end{array}$ \\
\hline $\begin{array}{l}2-5.9 \\
6-\text { over }\end{array}$ & $\begin{array}{l}4.5 \\
8.7\end{array}$ & $\begin{array}{l}72.8 \\
63.1\end{array}$ & $\begin{array}{l}45.2 \\
40.9\end{array}$ & $\begin{array}{l}191 \\
320\end{array}$ & $\begin{array}{l}2315 \\
2217\end{array}$ & $\begin{array}{l}582 \\
521\end{array}$ & $\begin{array}{r}-56 \\
-177\end{array}$ & $\begin{array}{l}4.5 \\
3.7\end{array}$ \\
\hline
\end{tabular}

It is important to note that expenses did not increase in direct proportion to the increase in farm income on the more profitable farms. The necessary overhead costs remain about constant on both profitable and unprofitable farms. The less profitable farms had a larger investment than the more profitable farms, while their production was almost $50 \%$ lower. (Table 35.)

In addition to efficiency of farm production, there appeared to be a slightly higher grade of livestock produced on some farms than was true of others. The prices received for steers and heifers by the more profitable farms was $\$ 68$ and $\$ 62$ per head, while low-income farms received only $\$ 61$ and $\$ 50$ per head, respectively. These two items constituted more than $60 \%$ of all cash receipts on beef farms.

\section{Organization and Combination of Enterprises}

There were only slight differences in the organization of enterprises on the high- and the low-income producing farms. Specialized beef production seemed to be organized in about the same general proportions, regardless of size and efficiency of unit, with few exceptions. There was no significant difference in the distribution of total investment on high-income farms versus low-income-producing farms, except in the case of livestock. The former possessed about four percent more of their total investment in livestock, which was the basic and major source of income. Greater income undoubtedly resulted from this arrangement. (Table 36.)

TABLE 35-Tiatio of expenses to receipts on high- and low-income-producing beef farms, 1936

\begin{tabular}{l|c|c|c}
\hline \multicolumn{1}{c|}{ Income group } & $\begin{array}{c}\text { Total } \\
\text { receipts }\end{array}$ & $\begin{array}{c}\text { Totai } \\
\text { expenses }\end{array}$ & $\begin{array}{r}\text { Ratio } \\
\text { of expenses } \\
\text { to receipts }\end{array}$ \\
\hline 15 farms with highest labor income & $\begin{array}{r}\$ 3008 \\
1598\end{array}$ & $\begin{array}{r}\$ 1804 \\
1642\end{array}$ & 102.7 \\
\hline \hline
\end{tabular}


Although the average crop acreage was less on the low-income farms, a larger percentage of their total receipts was from crop sales. The crop yield index was also much lower on these farms. As a result, cash crop production was unquestionably a very inefficient and unprofitable use of the land. There is general need for higher yields of grain and hay which may be fed to livestock.

The proportion of total receipts from the various livestock enterprises was about the same on both groups of farms. However, there was a slight tendency for the most profitable farms to obtain a greater proportion of their income from steers, rather than from other classes of livestock.

\section{Conclusions for Beef-Cattle Farms}

1. A medium-sized farming unit of between $200-250$ acres of pasture with 45 to 55 animal units seemed to be the most efficient.

2. The most profitable farms apparently were those with the best grade of pastures.

3. There appeared to be a definite need for pasture and cropyield improvement in order to make farming profitable in this area.

TABLE 36-Organization of high- and low-income-producing beef farms, 1936

\begin{tabular}{|c|c|c|}
\hline Factor & $\begin{array}{l}\text { Average for } \\
15 \text { high labor- } \\
\text { income farms }\end{array}$ & $\begin{array}{l}\text { Average for } \\
16 \text { low labor- } \\
\text { income farms }\end{array}$ \\
\hline $\begin{array}{l}\text { Fercentage of investment in: } \\
\text { Land } \\
\text { Dwelling } \\
\text { Farm buildings } \\
\text { Livestock } \\
\text { Other }\end{array}$ & $\begin{array}{r}54.7 \\
9.5 \\
13.1 \\
19.3 \\
3.4\end{array}$ & $\begin{array}{r}57.9 \\
11.4 \\
12.7 \\
15.4 \\
2.6\end{array}$ \\
\hline $\begin{array}{l}\text { Value of land per acre } \\
\text { Crop acreage }\end{array}$ & $\begin{array}{r}\$ 23 \\
57\end{array}$ & $\begin{array}{r}\$ 22 \\
47\end{array}$ \\
\hline $\begin{array}{l}\text { Percentage of crop land in: } \\
\text { Corn } \\
\text { Wheat } \\
\text { Hay }\end{array}$ & $\begin{array}{l}16.6 \\
16.9 \\
63.8\end{array}$ & $\begin{array}{l}15.8 \\
10.9 \\
68.8\end{array}$ \\
\hline $\begin{array}{l}\text { Percentage of total receipts from: } \\
\text { All livestock } \\
\text { Cows and heifers } \\
\text { Steers } \\
\text { Calves } \\
\text { Lambs } \\
\text { Livestock products } \\
\text { Crops }\end{array}$ & $\begin{array}{r}88.7 \\
13.4 \\
53.4 \\
10.5 \\
2.7 \\
11.2 \\
1.7\end{array}$ & $\begin{array}{r}89.1 \\
13.5 \\
\mathbf{5 0 . 9} \\
8.1 \\
\mathbf{1 . 7} \\
4.3 \\
5.9\end{array}$ \\
\hline $\begin{array}{l}\text { Percentage of total expense for: } \\
\text { Fertilizer and lime } \\
\text { seed } \\
\text { Feed } \\
\text { Labor }\end{array}$ & $\begin{array}{r}5.6 \\
4.9 \\
20.6 \\
43.2\end{array}$ & $\begin{array}{r}7.0 \\
5.9 \\
17.9 \\
52.9\end{array}$ \\
\hline
\end{tabular}




\section{SELF-SUFFICING FARMS}

Self-sufficing farms are those farms on which the value of farm products consumed by the family is $50 \%$ or more of the total value of all farm production. The term "self-sufficing" is inclicative of size of Lusiness rather than type of production. In terms of production they are small general farms. Twenty percent of all farms strveyed were classed as self-sufficing in the Jackson area. Their average size was 70 acres.

Insufficient size neccssarily limits and handicaps most types of agricultural production. Average units of 16 acres of crop land and 40 acres of very low quality pasture land definitely limit commercial production. Owing to a minimum of economic resources and credit from which to draw, the majority of such farms were capable of producing little more than a bare subsistence for the families.

The original productive capacity of most farms of this type has been reduced greatly by methods of farming that did not conserve fertility. Constant cropping on slope, the use of practically no lime or fertilizer, the inclusion of few legume or soil-building crops in the

TABLE 37-Investment possessed by more profitable and less profitable self-sufficing farms

\begin{tabular}{l|c|c}
\hline \multicolumn{1}{c|}{ Item } & $\begin{array}{c}\text { Average for 18 } \\
\text { more profit- } \\
\text { able farms }\end{array}$ & $\begin{array}{c}\text { Average for 19 } \\
\text { less profit- } \\
\text { able farms }\end{array}$ \\
\hline Total investment & $\$ 1445$ & $\$ 2400$ \\
Percent in land & 52.8 & 44.1 \\
Percent in dwelling & 17.3 & 24.3 \\
Percent in farm buildings & 8.5 & 13.7 \\
Percent in livestock & 17.5 & 3.7 \\
Percent in other & 3.6 & $\$ 15.30$ \\
Value of land per acre & $\$ 14.2 \mathrm{~S}$ \\
\hline \hline
\end{tabular}

production program, and unwise methods of cultivation have contributed to reducing yields seriously. Much of the present pasture land was formerly cropped until, because of depletion, it would no longer produce acceptably. The present situation is that all land has been seriously depleted, and no new land for crops is available in most instances. These farmers have been cut off from practically all sources of cash income, and their future economic condition will depend on their frugality, thrift, and ability to gain from their small farms the necessities of life.

\section{Size of Business}

The average investment in the more profitable self-sufficing farms was $\$ 1445$, compared to $\$ 2400$ for the less profitable. Significant in its implication, a greater proportion of the smaller investment was represented by land and livestock which were productive; while the larger investments consisted of dwellings and farm buildings in 
greater proportions. However, the difference was small and only slightly indicative of greater productive efficiency, inasmuch as the value of land was about the same for both highest and lowest income groups. (Table 37. )

The size of the farm business was small for all self-sufficing farms. The nore profitable ones consisted of smaller business units, having less acreage and fewer animal units of a different type that could be managed to greater advantage. It is clear that neither group possessed the physical basis for extensive production. There is definite necd for intensified effort in producing nore income and in improving the small acreage of available tillable land. (Table 38.)

TABLE 3S-Comparison of size of business on self-sufficing farms, 1936

\begin{tabular}{l|c|c}
\hline Measure of size & $\begin{array}{c}\text { Average for 1s } \\
\text { more profit- } \\
\text { able farms }\end{array}$ & $\begin{array}{c}\text { Average for 19 } \\
\text { less profit- } \\
\text { able farms }\end{array}$ \\
\hline Acres in farms & 66 & 74 \\
Crop acreage & 14 & 18 \\
Pasture acreage & 37 & 43 \\
Number animal units & 5.0 & 6.8 \\
\hline
\end{tabular}

\section{Oryanization of Farms}

The more profitable farms were organized on a more extensive plan than were the less profitable. They raised more corn and less hay and small grain, which was needed to maintain more poultry and fewer cattle. The less profitable self-sufficing farms were very small, inefficient livestock farms. (Table 39.)

The fact that the less profitable farms were endeavoring to produce cattle and hogs in excess of home needs seems to be indicative that they were organized improperly. Obviously, beef cattle and hogs cannot be produced profitably on a small scale. This is true because the costs per unit were necessarily excessive while the percentage of profit was small.

\section{Yiclds and Production}

Crop and pasture yields were extremely low on the self-sufficing

TABLE 39-Organization of more profitable and less profitable self-sufficing farms, 1936

\begin{tabular}{l|r|r}
\hline \hline \multicolumn{1}{c|}{ Content } & $\begin{array}{c}\text { Average for 1s } \\
\text { more profitable } \\
\text { farms }\end{array}$ & $\begin{array}{c}\text { Average for 19 } \\
\text { less profit- } \\
\text { able farms }\end{array}$ \\
\hline $\begin{array}{l}\text { Crop acreage: } \\
\text { Percent in corn }\end{array}$ & 40.4 & 24.6 \\
Percent in small grain & 5.9 & $\mathbf{1 5 . 4}$ \\
Percent in hay & 42.9 & 52.3 \\
Livestock: & & 3.0 \\
Number cows and heifers & 2.0 & .6 \\
Number steers & .4 & 2.5 \\
Number hogs & 1.4 & 59.0 \\
\hline \hline
\end{tabular}


farms. Based on the average yjelds for the state from 1923 to 1932 as 100, the average yield index on the more profitable farms was 49 , and 44 on the less profitable. The number of animal units pastured per acre was about half that of the average carrying capacity of pastures in the state. (Table 40.)

TABIE 40-Crop and pesture yield index and cash receipls on the more profilable and less profitalble sclf-sufficing fart.s, 19 !: $(;$

\begin{tabular}{|c|c|c|}
\hline Item & $\begin{array}{c}\text { Average for } 18 \\
\text { more profit- } \\
\text { able farms }\end{array}$ & $\begin{array}{c}\text { Average for } 19 \\
\text { less profit- } \\
\text { ible farms }\end{array}$ \\
\hline $\begin{array}{l}\text { Crop index } \\
\text { Acres pasture per animal unit }\end{array}$ & $\begin{array}{l}49.1 \\
11.5\end{array}$ & $\begin{array}{r}44.2 \\
8.5\end{array}$ \\
\hline $\begin{array}{l}\text { Total cash receipts } \\
\text { Percent livestock } \\
\text { Percent cattle and calves } \\
\text { Percent pigs } \\
\text { Percent poultry } \\
\text { Percent livestock products } \\
\text { Percent crops } \\
\text { Percent miscellaneous }\end{array}$ & $\begin{array}{r}\$ 167 \\
42.8 \\
14.7 \\
1.5 \\
23.7 \\
38.8 \\
3.9 \\
14.5\end{array}$ & $\begin{array}{r}\$ 181 \\
61.1 \\
35.5 \\
6.0 \\
9.4 \\
32.5 \\
2.6 \\
3.5\end{array}$ \\
\hline
\end{tabular}

The total cash receipts on these farms were exceedingly small. However, the more profitable farms produced the least average gross cash income. The greatest variation in sources of receipts between farms was between the various livestock enterprises. The more profitable farms derived the major portion of their cash receipts from poultry and eggs, while the less profitable derived their cash income from cattle and hogs. The less efficient group received an average of $\$ 17$ from poultry while the more efficient collected $\$ 40$ per farm from this enterprise. This illustrates the need for a change in organization of the less profitable farms, from cattle to smaller enterprises, requiring less grain and forage per unit of production. Poultry appears to offer one possibility. The scarcity of farm-grown feed and the relatively high price of purchased feed on these small, low-yielding farms makes the production of gains on cattle and hogs very unprofitable. Therefore, these small farms must be made to produce enough grain and forage for small enterprises by proper land management. (Table 41.)

It is significant that self-sufficing farms had less garden, truck, and fruits than the usual farm in the area. On the other hand, it is logical to assume that they should have more of such production than farms with more cash income. A general increase in this type of production would certainly enhance the income and general food supply of these farmers, and could be raised on the limited land area available.

\section{Expenses and Income}

Expenses on the less profitable farms showed a tendency to exceed receipts. The cost of livestock and feed purchased was excessive, considering the income received. Labor costs were also exces- 
TABLE 41-Gardcn, truck, and orchard grown on self-sufficing farms compared to other types of farming, 1936

\begin{tabular}{|c|c|c|c|}
\hline \multirow[b]{2}{*}{ Type of farm } & \multicolumn{3}{|c|}{ Average acreage per farm } \\
\hline & $\begin{array}{c}\text { Garden and } \\
\text { truck }\end{array}$ & Orchard & Small fruits \\
\hline SELF-SIFFICING ${ }^{2}$ & .71 & .74 & .02 \\
\hline General & 1.24 & 1.89 & .07 \\
\hline Beel & .86 & 1.10 & .. \\
\hline Dairy & 1.47 & 1.36 & .. \\
\hline Poultry & 1.04 & 1.34 & . \\
\hline Palt-tine & .83 & 1.35 & . \\
\hline Average all types & 1.05 & 1.45 & .04 \\
\hline
\end{tabular}

IIncludes potatoes.

'Average size of self-sufficing families was consistent with other types.

sive for the lowest income group, about two-thirds of which was the charge made for family labor. Consequently, there seems to be sufficient labor available to do a much more intensive type of farming than prevailed in 1936. It is evident that labor and feed were expencled on low-yielding enterprises, which resulted in a low total return per farm. (Table 42.)

The more profitable farms made a positive farm income and a labor income of $\$ 20$ after paying $5 \%$ on their investment. The investment in these farms was small, and the sources of receipts were more in line with the size and quality of resources available. In addition to an average labor income of $\$ 20$, these farm operators macle total earnings of $\$ 287$, inclucling $\$ 223$ as perquisites and $\$+4$ as $110 n$ farm income.

In contrast, the less profitable farms did not have enough receipts to balance the expenses. Therefore they lost money, allowing nothing for the capital invested or for the operator's labor and management. The average farm income was $-\$ 157$ and the average labor income - $\$ 277$. The value of perquisites and non-farm receipts resulted in an average operator's earnings of $\$ 45$ per farm.

TABLE 42-Expenses and income of more profitable and less mrofitable self-sufficing farms, 1936

\begin{tabular}{l|cc}
\hline \multicolumn{1}{c|}{ Ttem } & $\begin{array}{c}\text { Averagefor 18 } \\
\text { more profit- } \\
\text { able farms }\end{array}$ & $\begin{array}{c}\text { Averice for 19 } \\
\text { less profit- } \\
\text { able farms }\end{array}$ \\
\hline Tut cish exnenses & $\$ 119$ & $\$ 288$ \\
Percentage for fertilizer, lime, and seed & 2.5 & 6.5 \\
Percentage for livestock purchased & 17.6 & 15.2 \\
Percentage for feed purchased & 33.8 & 20.8 \\
Percentage for labor cost & 27.7 & 47.2 \\
Totil exnenses & $\$ 141$ & $\$ 375$ \\
Total receipts & 233 & 218 \\
Farm income & 92 & -157 \\
Labor income & 20 & -277 \\
Perquisites & 223 & 235 \\
Non-farm receipts & 44 & 87 \\
Operator's earnings & 287 & 45 \\
\hline
\end{tabular}


Eleven of the farms surveyed received $40 \%$ or more of their total farm income from the poultry enterprise. Although their number is small, this type of farming is important from the standpoint of a developing enterprise, where the demand for their products was reasonably good. The lessening ability of the smaller farms to maintain reasonable incomes from heavier livestock enterprises has lerl some general farmers into the production of chickens and eggs. Some have made the enterprise their major source of income.

The size of business unit and organization of production on poultry farms resembled that on the general farms in the same area, with the exception of slight differences in sources of income and the amount of investment. The average investment in poultry farms was $\$ 4780$, or about two-thirds that of general farms. The proportion of the total investment represented by varions capital items was similar to that on general farms, except that the dwellings were more valuable and the land of less value. The average value of land was $\$ 18$ per acre, which was very low considering that some land in the area was rated twice as valuable. However, the crop yield index was only 60 for these farms.

The size of farms and land-use signified a combination of general farm production with the major poultry enterprise. Each farm possessed an average of 15 animal units, slightly more than one-fifth of which was poultry. The usual combination of the minor enterprises was similar to that on general farms, except on a smaller scale. Low

TABLE 43-General characteristics of specialized poultry farms in Jackson area, $1936^{1}$

\begin{tabular}{lc}
\hline & Average per farm \\
\hline Number of farms & 11 \\
Average investment & $\$ 4780$ \\
Size of farm (acres) & 181 \\
Crop land (acres) & 41 \\
Pasture land (acres) & 100 \\
Number of animal units & $\mathbf{1 5}$ \\
Crop index & $\mathbf{6 0 . 1}$ \\
Pasture per animal unit & $\$ 897$ \\
Total cash receipts & $\$ 381$ \\
$\quad$ Livestock receipts & $\mathbf{5 2 . 7}$ \\
$\quad$ Percentage from poultry & $\$ 501$ \\
$\quad$ Percentage from eggs & 91.5 \\
Total cash expenses & $\$ 340$ \\
Percentage from feed & 62.3 \\
Total farm receipts & $\$ 1009$ \\
Total farm expenses & 822 \\
Farm income & $\$ 187$ \\
Labor incone & $\mathbf{5 3}$ \\
Value of perquisites & 427 \\
Non-farm income & $\mathbf{1 5 5}$ \\
\hline \hline
\end{tabular}

${ }^{1}$ Refer to Appendix for complete statistics on poultry farms. 
yields of crops and forage had evidently made it more desirable to depend on poultry, as a more intensive productive unit, than on general livestock. Farm receipts were more regular throughout the year. while receipts from beef cattle were periodic.

The arerage total cash receipts on poultry farms were $\$ 897$. Livestock sales represented $\$ 381$, of which $53 \%$ was from poultry. Livestock products accounted for $\$ 501$ per farm, of which $92 \%$ was receipts from eggs. (Table 43.)

Feed costs constituted $62 \%$ of all cash expenses on these farms. However, this does not seem excessive when the total cash expenses are compared with total receipts. It is evident that thesc farmers found it more desirable to purchase a portion of their concentrated poultry feed than to purchase both bulky and concentrate feeds for cattle and hogs, from which their rate of return would be much less. A unit of feed fed to poultry will return a greater value in salable products than when fed to beef cattle. ${ }^{8}$

The average farm income for poultry farms was $\$ 187$. which lacked $\$ 53$ of equaling a $5 \%$ return on the average investment. As. a result, there was no return to the operator for his labor and management. The total of labor income, perquisites, and non-farm receipts made the average operator's earnings $\$ 529$. These earnings represent the return to the operator after deducting a charge of $5 \%$ for the use of capital.

Poultry farms were generally profitable to the extent that available labor was used with a fair degree of efficiency, and the returns on a small investment were sufficient to make possible a reasonable standard of living for the farm family.

\section{PART-TIME FARMS}

Part-time farming is a type of agriculture in which the farm operator spends at least the equivalent of 150 days at work not comnected with his farm, provided the total value of products from the farm does not exceed $\$ 750$. This type of farming prevails in industrial areas where farming can be made a supplementary source of income.

The organization of this type of farming is quite like that of selfsufficing farms. The units are small, land is generally of low value, and productivity is not maintained, while practically all products are consumed on the farm. Their average size was 80 acres, $15 \%$ of which was crop land, and $60 \%$, pasture. (Table 44.)

The productive capacity of most of these farms was very low, rescmbling that of self-sufficing farms in most cases. The average crop index was 41.9, with eight or more acres of pasture per animal unit. It is evident that these small farms of low-yielding land are not capable of producing profitably under an extensive system. However, more than $50 \%$ of their total farm receipts was derived from heary livestock in 1936, while poultry produced $40 \%$ of all cash receipts.

sHenry and Morrison, Feeds and Feeding, 19th edition, p. 92, The HenryMorrison Company, 1928. 
Total cash farm expenses

Percentage for feed

$$
\begin{array}{r}
10 \\
\$ 3586 \\
80 \\
12 \\
48 \\
5.7 \\
41.9 \\
8.4 \\
\$ 193 \\
124 \\
17.9 \\
\$ 52 \\
67.3 \\
\$ 209 \\
43.1 \\
\$ 221 \\
520
\end{array}
$$

Total farm receipts

Total farm expenses

Farm income

Labor income

Value of perquisites

Non-farm income

Operator's earnings

${ }^{1}$ Refer to Appendix for complete statistics on part-time farms.

The area devoted to garden and truck averaged about 0.83 of an acre per farm. Since this type of farmer is seeking a more satisfactory livelihood by living on a farm, it seems that by expanding the same amount of labor and capital on more intensive production such as truck, poultry, and small fruits, earnings could be increased. Such enterprises could be confined to the best available land, while the land of poorer quality could be improverl by extensive methods requiring a minimum of effort.

In 1936 about $43 \%$ of the total cash expenses was expended for feed, a major portion of which was for inefficient cattle production. It is possible that a greater part of this expenditure for poultry feed would produce a much greater net income.

Part-time farms were generally operated at a loss, from the standpoint of both farm income and labor income. However, the value of perquisites consumed by the farm family exceeded the loss in farm income. Perquisites in the amount of $\$ 385$ together with average non-farm receipts of $\$ 739$ netted the farm operators average earnings of $\$ 647$.

Undoubtedly, greater operator's earnings could be derived if more attention were given to improving soil productivity, and producing types of enterprises more adapted to the size of farm and the labor available. Certainly some attention should be given to landuse practices which would improve and prolong the productivity of the land that is now available for this type of livelihood. 
Specialized dairy production is practiced by only a few farms in this area. Seven farms vere classified as obtaining $40 \%$ or more of their total receipts from the dairy enterprise. The most economical production of dairy products, like efficient beef-cattle production, requires pastures of reasonably high quality, together with good forage. Consequently, the low-quality pasture and meadow land, representing a large portion of this area, is not particularly adapted to dairy farming. However, in many instances improvement in the quality of pasture and forage might provide the requisites for profitable dairy production. The average crop yield index and the average animal units maintained per acre of pasture were higher for dairy farms than for any other type of farm. This signifies that such requisites are recognized. As a result, dairy farming at present is limited to the higher-quality land.

The average size of dairy farms was 204 acres, or about a third smaller than that of beef farms. Their average investment also was appreciably less than on the larger beef farms. With this exception, dairy farms exceeded all other types in size and value. There were about 139 acres of open pasture available per farm for 17 dairy cows, in addition to nine animal units of other livestock. (Table 45.)

Cash farm receipts were considerably larger on dairy farms than

TABLE 45-General characteristics of specialized dairy farms in Jackson area, 1936 ${ }^{1}$

\begin{tabular}{|c|c|}
\hline Item & Average per farm \\
\hline $\begin{array}{l}\text { Number of farms } \\
\text { Average investment } \\
\text { Average size of farms (acres) } \\
\text { Crop land (acres) } \\
\text { Pasture land (acres) } \\
\text { Animal units } \\
\text { Dairy cows (number) }\end{array}$ & $\begin{array}{r}7 \\
\$ 10,759 \\
204 \\
40 \\
139 \\
26 \\
17\end{array}$ \\
\hline $\begin{array}{l}\text { Crop index } \\
\text { Pasture per animal unit (acres) }\end{array}$ & $\begin{array}{r}89 \\
5\end{array}$ \\
\hline $\begin{array}{l}\text { Total cash farm receipts } \\
\text { Livestock receipts } \\
\text { Percentage from cows } \\
\text { Livestock products receipts } \\
\text { Percentage from milk }\end{array}$ & $\begin{array}{r}\$ 3581 \\
461 \\
44 \\
\$ 3057 \\
93\end{array}$ \\
\hline $\begin{array}{l}\text { Total cash expenses } \\
\text { Percentage for feed }\end{array}$ & $\begin{array}{r}\$ 1416 \\
63\end{array}$ \\
\hline $\begin{array}{l}\text { Total farm receipts } \\
\text { Total farm expenses }\end{array}$ & $\begin{array}{r}\$ 3997 \\
2489\end{array}$ \\
\hline $\begin{array}{l}\text { Farm income } \\
\text { Labor income } \\
\text { Value of perquisites } \\
\text { Non-farm income } \\
\text { Operator's earnings }\end{array}$ & $\begin{array}{r}\$ 1508 \\
958 \\
425 \\
180 \\
1563\end{array}$ \\
\hline
\end{tabular}

${ }^{1}$ Refer to Appendix for complete statistics on dairy farms. 
on any other type. More than $90 \%$ of all receipts were derived from the sale of milk and dairy cows. This type of farm is more specialized and depends to a greater extent on a single enterprise than any other type of farm. However, milk is in general denand throughout the year, with only minor variations in demand from year to year. Thus the demand for production of this type is probably more stable than for any other commodity produced in the area.

Coincident with a large volume of receipts per farm, the expenses were comparatively low. Farm income exceeded that of beef cattle farms threefold. It is quite possible that present expenses can be diminished by producing a higher quality of forage which may partially replace a feed bill that represented $63 \%$ of all expenses in 1936. In this case, farm income could be further increased.

Dairy farms were the only type of farms to produce an average positive labor income, which was $\$ 958$ per farm. In addition, the farms furnished perquisites valued at $\$ 425$ per farm, and the farm operators derived an average of $\$ 180$ from non-farm sources. Thus operator's earnings amounted to $\$ 1563$ per farm. It is pointed out that this sum was the amount remaining to pay the operator for his labor and management after all expenses and a charge of $5 \%$ for the use of capital had been deducted from receipts.

Unless there are definite and permanent limitations to the expansion of the dairy industry in this section, there undoubtedly will be an increase in the number of dairy farms in the future. Large capital requirements, lack of knowledge of the industry, and a scarcity of good land represent practical handicaps to a rapid expansion of dairy farming in this area. The improvement of pastures and higher quality legume forage may encourage the expansion of this type of farming.

\section{The Program of Soil Conservation in the Jackson Area}

The general program of the Soil Conservation Service is reviewed briefly in the following discussion in order that it may be possible to point out clearly the association of its various phases with the factors of production.

\section{(1) Pasture Improvement}

On June 1, 1937, 68 farms consisting of 15,730 acres were under five-year agreements in this area. A total of 9,798 acres of pasture land had been converted from uncontrolled to controlled management. This type of management may be partially illustrated by the following excerpts from an agreement: (a) "All pasture land under agreement suitable for mowing will be mowed the last of June and again the first of September if necessary to control weeds." (b) "Livestock will be removed sufficiently early in the fall to insure growth for winter protection, and will not be turned on in the spring until pas- 
tures are started sufficiently to prevent injury." Pasture rotations are to be followed where needed and possible.

A total of 561 acres of pasture had been completely reseeded; 389 acres treated with lime and superphosphate; and 355 acres treated with mixed fertilizer, according to needs of varions local conditions. In places where pasture sods are weak and slopes are steep, the land is contour-furrowed to retard run-off and to facilitate the percolation of water jinto the soil. These methods are designed to make possible the grazing of reasonably steep land without permitting continuous unchecked erosion to destroy future productivity.

The improvement of pastures by better managcment, fertilization, liming, reseeding, mowing, according to definitely planned programs, is essential for erosion control in this area, and will undoubtedly enhance farm production. Pastures are the foundation of agriculture in this state. The efficient growing of a greater number of animal units, of better quality, undoubtedly will contribute to higher incomes. The proportion of the total agricultuial income which is derived from livestock has increased from about $50 \%$ to $70 \%$ during the last decade. During the same period the total agricultural income of the state has decreased. Consequently livestock and the necessary maintenance constituents are growing in importance. Obvionsly how far to go in outlays of cash and other resources for such pasture improvement is a question confronting the farmer.

\section{(2) Yield Improvement}

Another objective of soil conservation is to improve hay and grain yields by rotation of fertility-building crops, fertilization and soil and moisture conservation. These will contribute to the efficient production of livestock and improvement of farm income. Yields of both hay and grain have been exceedingly low in past years. Hence crops of high-yielding ability together with improvement of soil fertility are urgently needed. In order that soil depletion may be checked and productive capacity increased, systematic crop rotations, providing better soil cover for preventing erosion, have been planned for 2,821 acres, or three times the amount of land that was cultivated and managed systematically before the agreements were signed.

\section{(3) Improvement and Conservation of Soil Fertility}

The conservation program plans the improvement and conservation of soil fertility by growing soil-conserving and fertility-building crops. The 68 farms had 2,005 acres of cultivated or non-erosionresistant crops. This acreage was reduced to 1,304 acres, or $35 \%$, by the conservation agreements. Semi-erosion-resistant small grains are planned to be increased from 351 acres to 596 acres, or $70 \%$. Erosionresistant hays and forage crops have been increased in acreage from 742 to 979 , or $32 \%$. The acreage of permanent legume hays were increased from 526 to 905 acres, or $72 \%$. These erosion-resistant crops will replace cultivated crops where possible. 
These changes, from a type of production conducive to soil erosion and fertility depietion, to erosion-resistant and fertility-building crops appear to be in accord with the general needs for correcting land abuse in the area. In addition, legumes shoulrl build up the nitrogen content of soil, which is invaluable in forage and pasture production.

\section{(4) Lime and Ferlilizer.}

Lime and fertilizer have been applied to all land sown to legume hays. Both hay and grain yields will eventually profit by reason of these practices, as grain will follow legume hays in the planned rotations.

However, unless there is comparatively level land available for grain production in excess of that needed to grow sufficient hay, grains are to be largely purchased. The tendency, therefore, is toward less acreage of concentrate grain feeds on low yielding land. With the exception of small, self-sufficing farms, grain feeds required should largely be purchased. Grains can be purchased to a greater advantage than hay. It is entireiy possible that alfalfa and clover hays of comparatively high quality may effectively replace an appreciable amount of the grain now fed to clairy cows and other cattle. But enough grain should be produced for hogs and chickens to be consumed by the farm family, particularly on the small farms.

\section{(5) Farm Organization and Management}

The planned programs of conservation for individual farms include features of farm organization and management which should contribute to more efficient long-time production. Land use and cropping patterns are organized so that the various crops and pasture are grown on the soil for which they are best adapted. Systems of crop and pasture rotations are planned for the improvement of soil fertility, greater productive efficiency, and the retardation of erosion. If such plans are correctly made they will improve the balance of production, and will contribute to the more efficient utilization of all resources for the continued production of income. It may be well to state that the organization of all minor and supplementary or complementary enterprises must be planned so as to contribute the most to the efficient production of the major enterprise.

\section{(6) Vegetation and Cover}

The plans for conserving soil and water are designed to provide an erosion-resistant cover of some desirable nature for all land which will retard run-off of rainfall and check soil depletion.

\section{(7) Engineering}

In addition to management and better agronomic practices, cer- 
tain engineering features of the conservation program are planned. (a) Strip-cropping of sloping land that must be used to grow crops is intended to check erosion and to encourage percolation of water into the soil. About 494 acres of crop land will be strip-cropped on the 68 farms. This practice should conserve soil fertility and crop yields over a period of years. (b) Contour furrows for pasture land and drainage areas for crop lands are installed to retard sheet erosion and gullying, and to increase the percolation of water into the soil instead of permitting it to escape unused over the surface. These measures serve a definite need if constructed properly and given proper attention as the program progresses.

\section{(8) Forest Plantings}

In addition to engineering structures, forest plantings are provided to protect and improve severely-eroded areas and to produce desirable wood and timber for the farms. The introduction of new plants having unusual ability to protect areas that normally erode rapidly will tend to reduce the total amount of soil erosion.

In general, the entire program of soil and water conservation is designed to conserve the resources of agriculture, the principal one of which is soil productivity. The above data, showing the scope and extent of applied conservation measures on the 58 farms, anticipate the completion of all stipulations set forth in the respective contracts. Not all have been completed to date. Some changes are comprehensive in nature and may require several years for completion.

\section{FARM PLANNING}

Erosion control and conservation practices must be evaluated in light of the physical and economic organization of the farm unit. The farmer, in most instances, cannot adjust his program suddenly, and possibly may not be able to do it at all if his farm does not offer the necessary physical and economic basis for shifting sources of income from soil-depleting enterprises to soil-conserving enterprises.

The application of an erosion control program must be on the basis of the individual farm. All farms cannot be made to fit a uniform standard program. Each farm is a separate economic production and consumption unit which must not be ignored in attempts at conservation. The farm as a crop and livestock producing unit, must continue to be used for gaining a livelihood. The best erosionresistant cover that possibly could be grown on a given farm probably would be forest or a good pasture sod, but farmers cannot live by these alone. In order that conservation practices may be accepted they must become part of a well-balanced farm organization program which will permit the farm family to live better and with greater security than was possible under the soil-depleting system of production.

If the recommended program of conservation will not maintain 
or enhance the farmer's economic status, the facts must be admitted. The present need is to give economic sufficiency to the farmer now on the land. However, it undoubtedly is possible to develop a satisfactory program of soil conservation that will enhance farm income and standards of living in most farming areas if proper attention is given to balancing the production program according to both the agronomic and livestock needs of the farm. Where this is not possible non-agricultural land uses should be provided, and farming should be discouraged.

The type of production cannot be changed on many farms because of limited land resources. The small general-self-sufficing farm must raise a variety of commodities for family use. Corn and wheat are almost essential to their proper functioning, just as pasture and forage are essential to beef and dairy farming. The small farms must be made to produce as much as possible, with proper attention to conserving soil fertility. They cannot specialize in grass or grains. A balanced program of production must be followed that will furnish food to the family, and grains to poultry, hogs, and a small number of other livestock. Owing to the lack of production for sale or exchange the small farms should be as independent and self-sufficing as possible, requiring a minimum of purchased supplies.

Care should be exercised in replanning farms so that crop rotations function properly. In converting crop land to meadow the change should be worked into the rotation gradually in order that the proper balance is maintained between grain and forage crops in all succeeding years. Farm organization cannot be changed suddenly from year to year. The volume of grains and forage should be produced in about the same proportions each year to suffice the needs of a more or less stable livestock program. A well-planned farm program should be a completely "well-rounded" production schedule, suitable to proper land use, soil and water conservation, the economic resources of the farmer, and the production needs of both livestock and the farm family.

\section{Summary}

The nature of the development of agricultural production in West Virginia has been responsible for the evolution of many problems in connection with land use. The misuse of land, wasteful cropping practices, and lack of practical management have resulted in lowyielding crop and pasture land. Erosion of soil has practically destroyed many acres of sloping land and has depleted a larger area of much of its most valuaivie productive capacity. As a result, production has become more inefficient and farm income has been decreasing. Likewise the security of the people has been jeopardized.

The inception of the Soil Conservation Service was a move by the Federal Government to assist the farmers in solving the problems of soil and water conservation. This agency has established eight demonstration areas in West Virginia for demonstrating the best 
methods of erosion-control and soil-building practices.

The Jackson area, S.C.S.W.VA.-6, is studied here as typical of the problems in soil conservation, and typical of the work being undertaken. In this demonstration area several methods of attack are being demonstrated. In general they consist of:

(1) using land for the purpose to which it is best adapted;

(2) decreasing the acreage of non-erosion-resistant crops on sloping land that is subject to serious erosion;

(3) introducing erosion-resistant crops to take the place of grains and low-quality hays which do not supply the sloping land with sufficient uniform cover;

(4) improving soil fertility of both crop and pasture land by liming, iertilization, crop management and rotation, and growing adaptable crops;

(5) using engineering methods and field arrangement for the control of sheet erosion and gully washing;

(6) managing all land, including forests, waste land, and farm iand to provide the best cover that is possible and practical to maintain for the ittardation of erosion.

Analysis of agricultural production in this area indicates that the most outstanding needs from an economic standpoint are: (a) more efficient production of good-quality pasture and hay for stuppost of the more profitable livestock enterprise; (b) general improvement in crop and pasture yields; and (c) definite changes in systems of management, types of crops grown, and farm organization on the farms of different types.

The opportunity to utilize available labor and land resources to best advantage apparently exists in poultry and dairy production, where land suitable for pasture and forage is limited. Specialized beef cattle, sheep, and general livestock production are suitable only for larger farms. With varying physical resources and different economic advantages, all farms cannot be of one type. The success of the smaller farm depends on the utilization of its limited resources in a comparatively intensive manner, employing proper conservation practices while producing a self-sufficient livelihood for the farm families that depend on them.

It appears that the work of the Soil Conservation Service may demonstrate methods of satisfying the above needs and for correcting the misuse and abuse of land prevailing in the area. The planned programs will undoubtedly have a positive effect in the improvement of the land resources upon which the major agricultural enterprises of the state depend. As a result, agricultural production should be improved, if the plans are properly made, consistent with needs of various types of farms, to the extent that annual farm income will be maintained or increased. The improvement and maintenance of soil fertility should prolong the period of usefulness of the soils. Consequently, the standard of rural living should be enhanced and stabilized, making the farmers more self-reliant and the farms of West Virginia more desirable homesteads. 


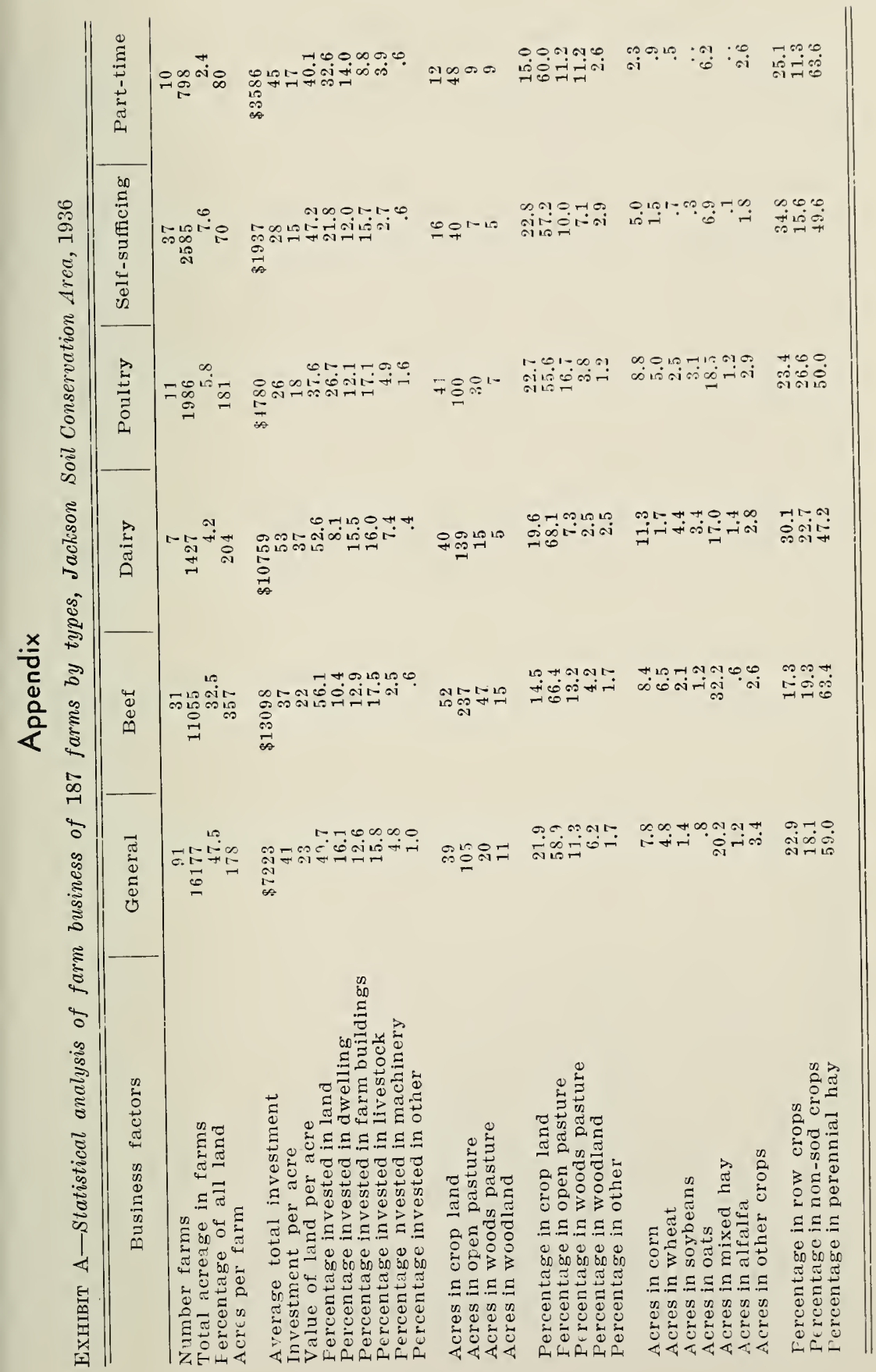




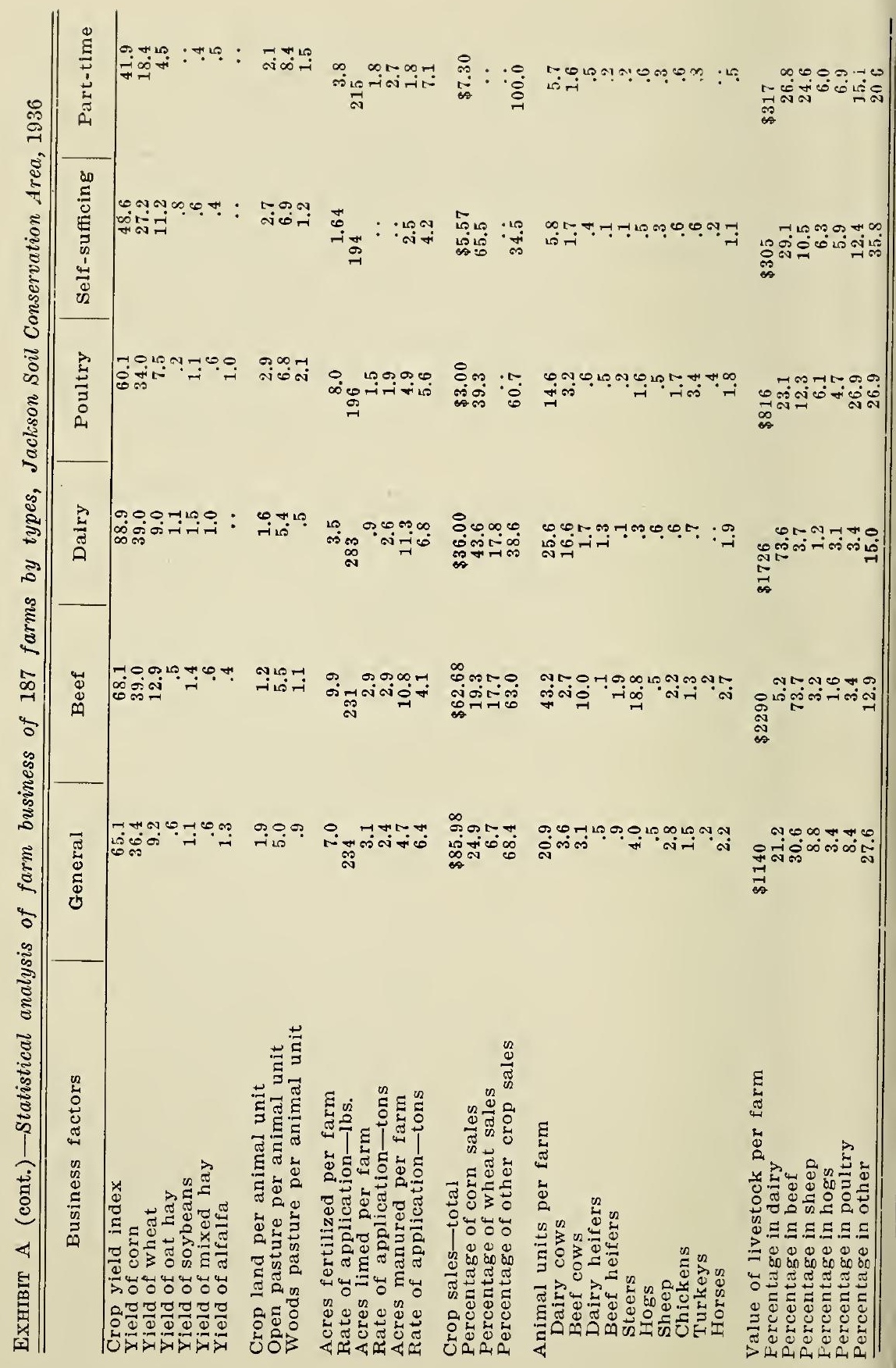




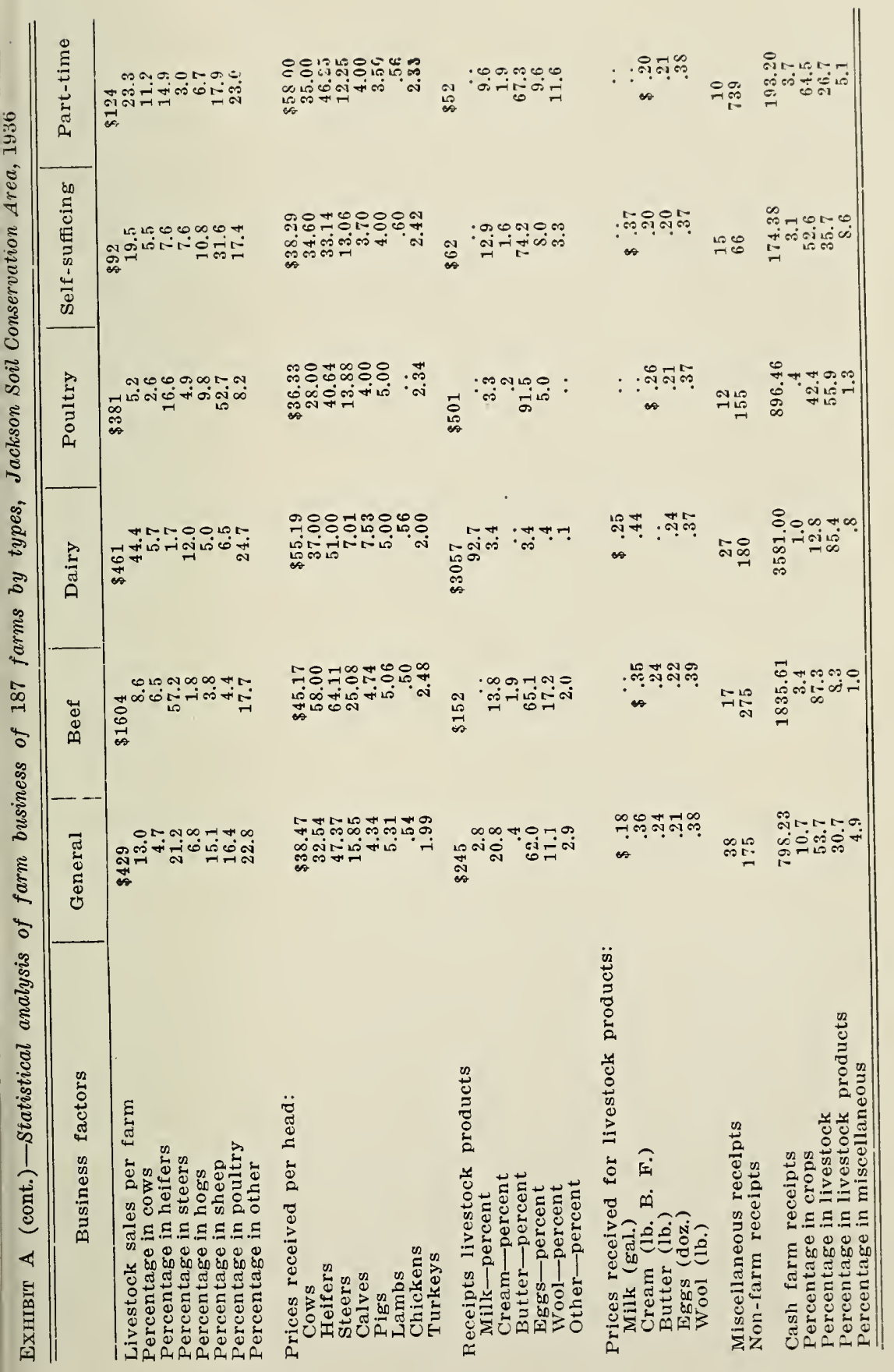




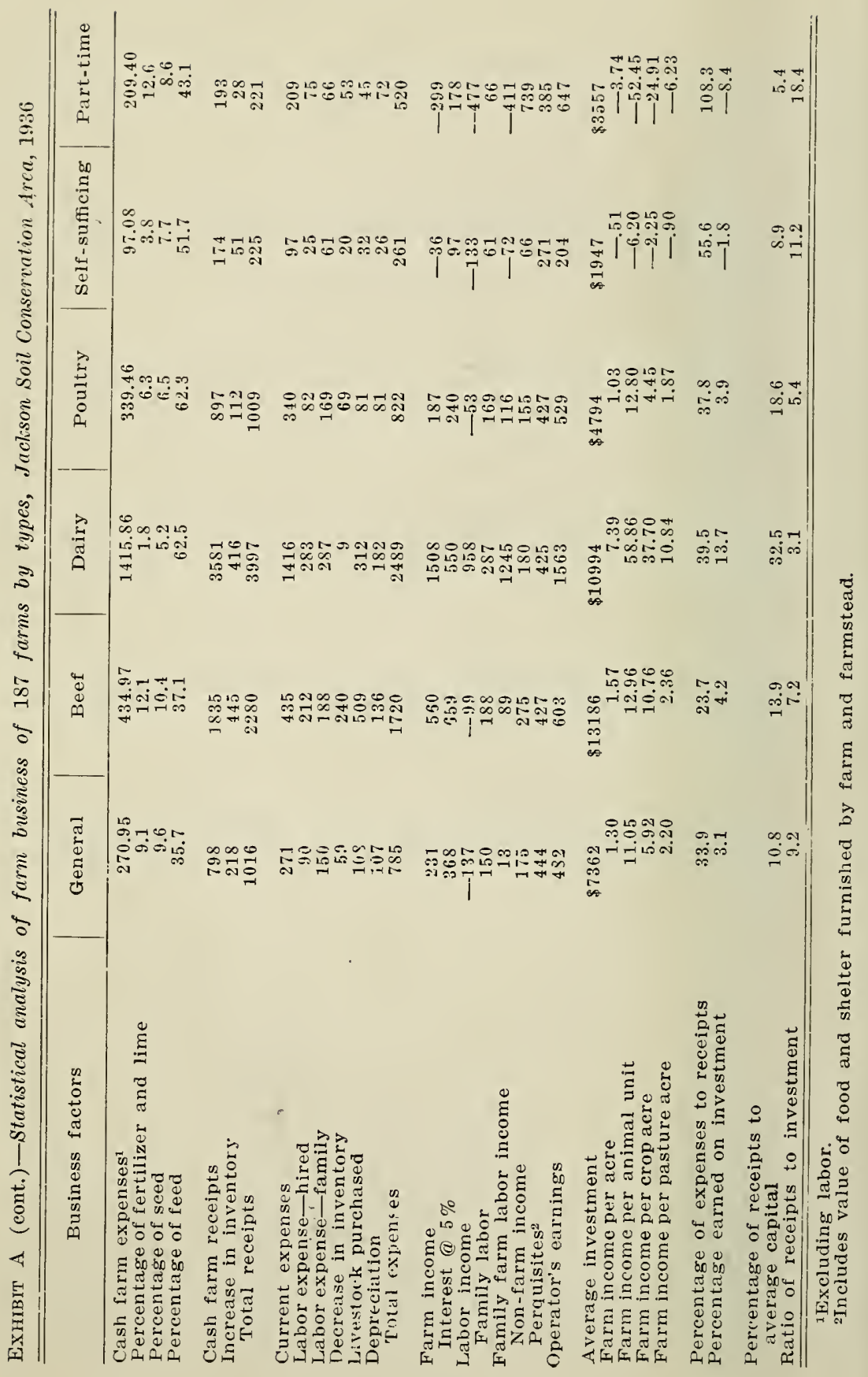


